\title{
Interim Progress Report - Geophysics: Building E5282 Decommissioning, Aberdeen Proving Ground
}

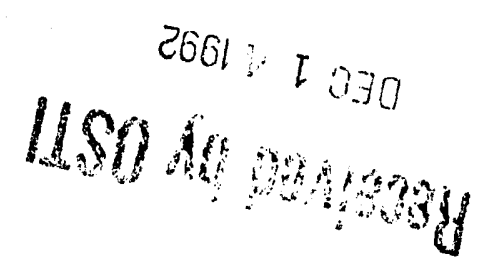

Energy Systems Division Argonne National Laboratory

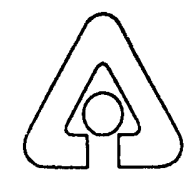

Operated by The University of Chicago, under Contract W-31-109-Eng-38, for the

United States D̄epartment of Energy 


\section{Argonne National Laboratory}

Argonne National Laboratory, with facilities in the states of Illinois and Idaho, is owned by the United States government, and operated by the Univeisity of Chicago under the provisions of a contract with the Department o: Energy.

This technical memo is a product of Argonne's Energy Systems (ES)

Division. For information on the division's scientific and engineering activities, contact:

Director, Energy Systems Division

Argonne National Laboratony

Argonne, Illinois 60439-4815

Telephone (708) 252-3724

Presented in this technical memo are preliminary results of ongoing work or work that is more limited in scope and depth than that described in formal reports issued by the ES Division.

\section{Disclaimer}

This report was prepared as an account of work sponsored by an agency of the United States Govemment. Neither the United States Govemment nor any agency thereof, nor any of their employees, makes any warranty, express or implied, or assumes any legal liability or responsibility for the accuracy, completeness, or usefulness of any information, apparatus, product, or process disclosed, or represents that its use would not infringe privately owned rights. Reference herein to any specific commercial product, process, or service by trade name, trademark, manufacturer, or otherwise, does not necessarily constitute or imply its endorsement, recommendation, or favoring by the United States Govemment or any agency thereof. The views and opinions of authors expressed herein do not necessarily state or reflect those of the United States Govemment or any agency thereof.

Reproduced directly from the best available copy.

Available to DOE and DOE contractors from the Office of Scientific and Technical Information, P.O. Box 62, Oak Ridge, TN 37831; prices available from (615) 576-8401.

Available to the public from the National Technical Information Service, U.S. Department of Commence, 5285 Port Royal Road, Springfield, VA 22161. 


\section{Interim Progress Report - Geophysics: Building E5282 Decommissioning, Aberdeen Proving Ground}

by M.D. Thompson, M.G. McGinnis, L.D. McGinnis, and S.F. Milier

Reclamation Engineering and Geosciences Section, Energy Systems Division, Argonne National Laboratory, 9700 South Cass Avenue, Argonne, Illinois 60439

August 1992

Work sponsored by United States Army, Aberdeen Proving Ground, Maryland 
This document is printed on recycled paper with the exception of color reproductions. 


\section{Preface}

This report is one of a series on geophysical surveys around perimeters of buildings in the Canal Creek area of the Edgewood section of Aberdeen Proving Ground. The series was initiated in 1991 at Building E5032, where geophysical techniques were tested and a design for the surveys was established. The series continued in 1992, when surveys of Buildings E5190, E5282, E5375, E5440, E5476, E5481, E5485, E5487, E5489, and E5974 were completed. The surveys and reports were done sequentially, with lowest building numbers being completed first. For this reason, deeper insight into the magnetic, electrical, and radar imagery characteristics of the Canal Creek area was gained with progressively increasing building numbers. A survey at the Building 103 Dump, also completed during the spring of 1992, was not specifically designed to assist building decommissioning. This survey is included in the series because it was conducted by our geophysics team using techniques and procedures identical to those for the building decommissioning surveys. 


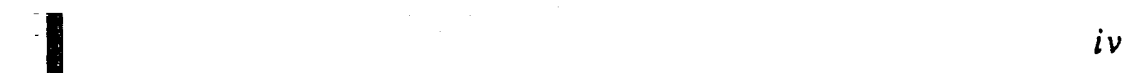




\section{Contents}

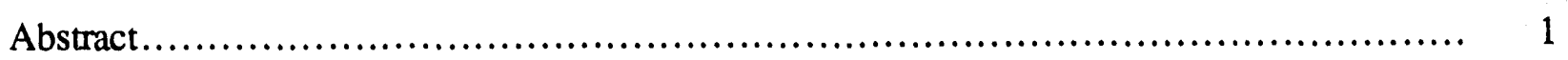

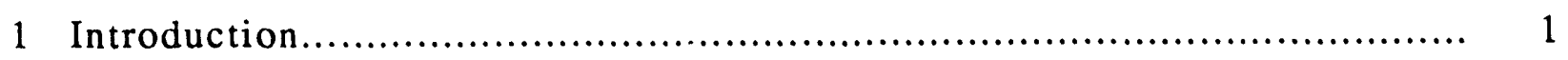

1.1 History of Building E5282 ................................................. 3

1.2 Site Reconnaissance....................................................... 6

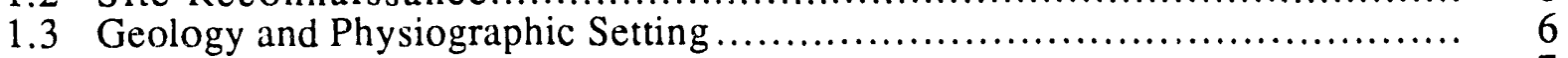

1.4 Surveys........................................................................ 7

1.5 Survey Grid and Locations of Observations ................................ 8

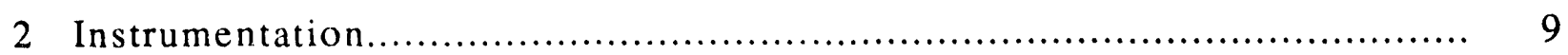

2.1 Magnetic Gradiometer and Cable Locator..................................... 9

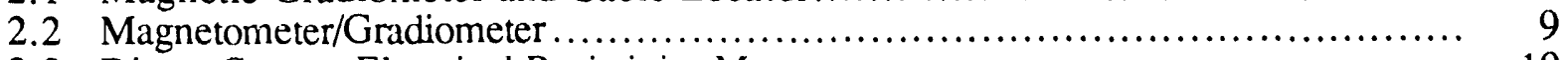

2.3 Direct-Current Electrical Resistivity Meter.................................... 10

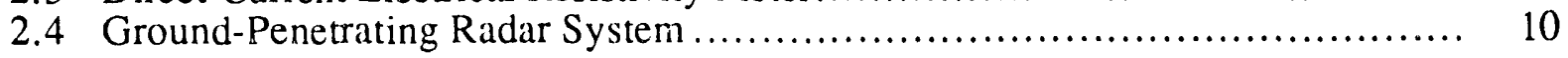

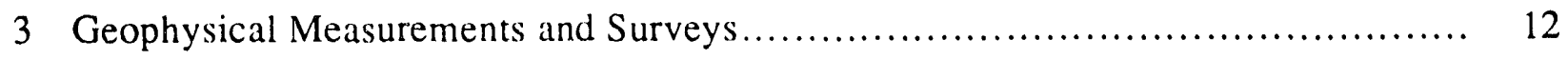

3.1 Magnetometer Measurements ........................................... 12

3.2 Direct-Current Electrical Resistivity Measurements.................................. 14

3.3 Ground-Penetrating Radar Measurements................................. 17

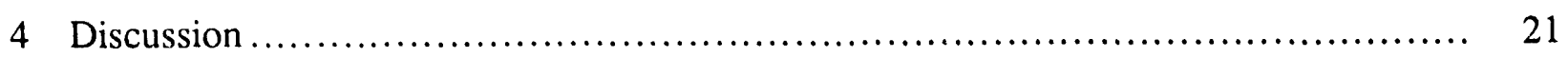

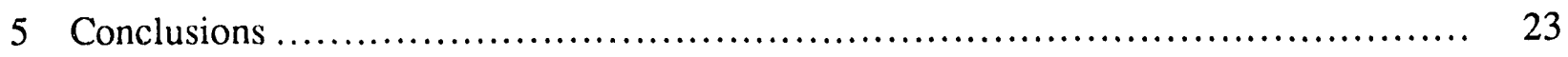

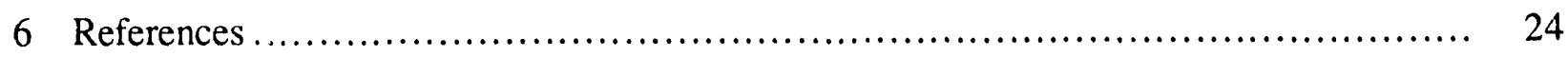

Appendix A: Electrical Depth-Sounding Curves................................... 25

Appendix B: Ground-Penetrating Radar Line Coordinates ........................... 33

\section{Tables}

$1 \quad$ Lithologic Log of Borehole at Site No. 23 .................................... 7

2 Approximate Two-Way Travel Times for Various Materials ....................... 11

A.1 Location of Centers of Stations and Orientations of Electrode Arrays for Schlumberger Electrical Depth-Soundings at APG.

A.2 Resistivity Models Calculated from Electrical Depth-Soundings. 


\section{Figures}

1 General Site Map of the Canal Creek Area, Aberdeen Proving Ground, Md..... 2

2 General Location Map of Building E5282 ..................................... 4

3 Geophysical Survey Boundaries for Building E5282 .......................... 5

4 Total Intensity Magnetic Map of Building E5282 ............................. 13

$5 \quad$ Apparent Resistivity Map of Building E5282 ................................ 15

6 West-East Ground-Penetrating Radar Profile for the Area West of Building E5282 ............................................................ 16

7 North-South Ground-Penetrating Radar Profile for the Area North

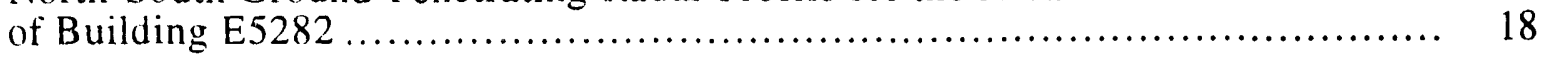

8 North-South Ground-Penetrating Radar Profile for the Area East of Building E5282 ............................................................ 20

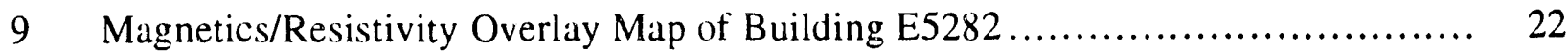

A.1 Electrical Depth-Sounding Curve Near Building E5282 .......................... 29

A.2 Electrical Depth-Sounding Curve Near Building E5440 ........................ 30

A.3 Electrical Depth-Sounding Curve Near Building E5481 ........................ 31

A.4 Electrical Depth-Sounding Curve Near Building E5974 ......................... 32 


\title{
Interim Progress Report - Geophysics: \\ Building E5282 Decommissioning, Aberdeen Proving Ground
}

by

\author{
M.D. Thompson, M.G. McGinnis, \\ L.D. McGinnis, and S.F. Miller
}

\begin{abstract}
Building E5282 was one of 10 potentially contaminated sites in the Canal Creek area of the Edgewood section of Aberdeen Proving Ground examined by a geophysical team from Argonne National Laboratory in April and May of 1992. Noninvasive geophysical surveys, including magnetics, electrical resistivity, and ground-penetrating radar (GPR), were conducted around the perimeter of the building to guide a sampling program prior to decommissioning and dismantling. Magnetic surveys identified small, complicated, multiple anomalies west, north, and northeast of the building that may be caused by construction fill. Two underground storage tanks, at the northeast and southeast corners, were identified. A large magnetic anomaly complex east of the building was caused by aboveground pipes and unexploded ordnance fragments scattered at the surface. Electrical resistivity profiling showed a broad, conductive terrain superimposed over magnetic anomalies on the north and west. A broad, high-resistivity, nonmagnetic area centered $25 \mathrm{ft}$ east of the building has an unknown origin, but it may be due to nonconductive organic liquids, construction fill, or a buried concrete slab; GPR imaging showed this area as a highly reflective zone at a depth of about $5 \mathrm{ft}$. The GPR data also showed a small-diameter pipe oriented north-south located east of the building.
\end{abstract}

\section{Introduction}

Aberdeen Proving Ground (APG), in the state of Maryland, is currently managing a comprehensive Installation Restoration Program involving more than 360 solid-waste managing units contained within 13 study areas. The Edgewood area and two landfills in the Aberdeen area appear on the National Priority List under the Comprehensive Environmental Response, Compensation, and Liability Act. Therefore, APG has entered into an Interagency Agreement with the U.S. Environmental Protection Agency to address the listed areas.

The West Branch of the Canal Creek area (Figure 1) is one of the areas that requires a Source Definition Study because there is an ongoing release of volatile organic compounds into the 


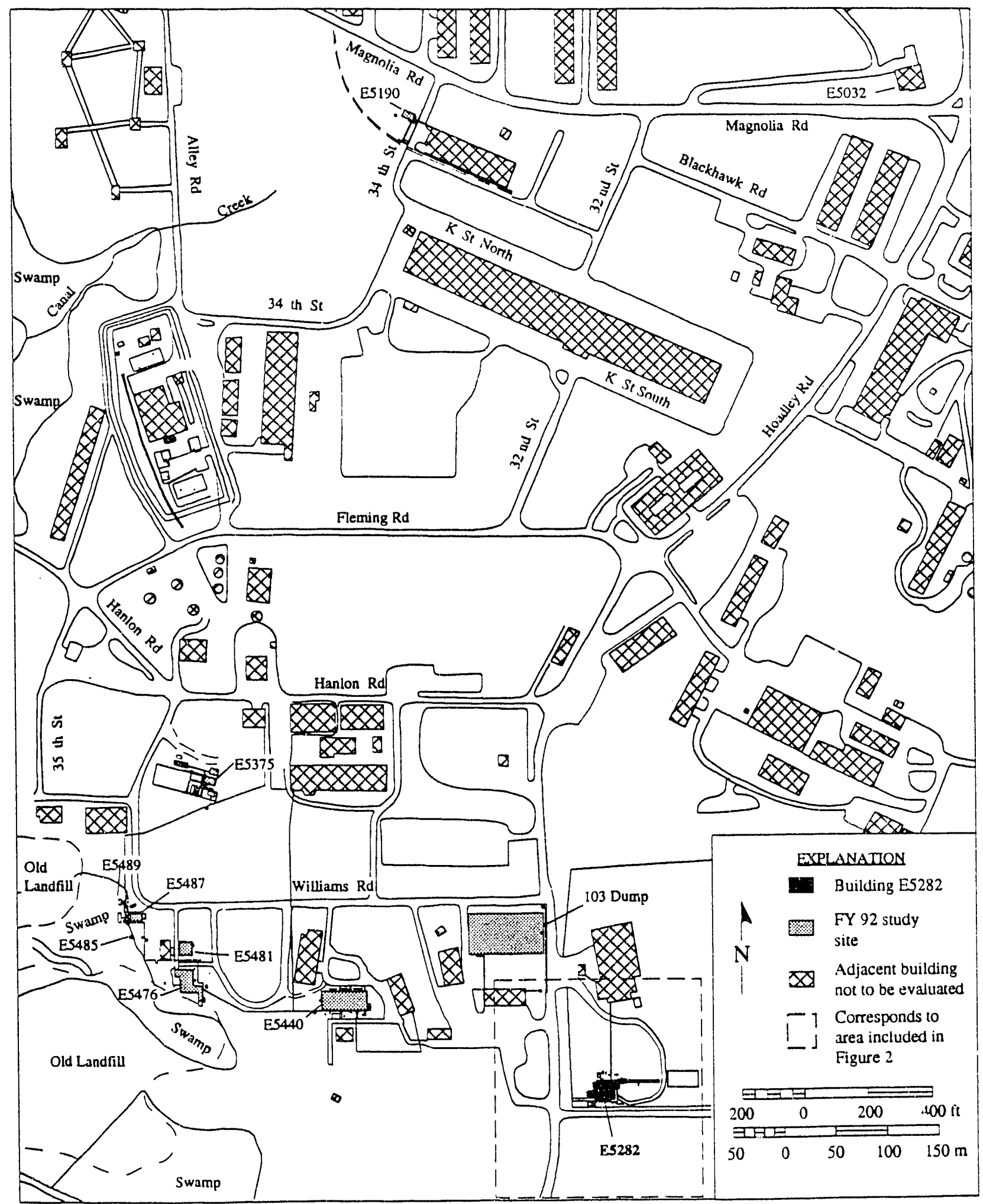

FIGURE 1 General Site Map of the Canal Creek Area, Aberdeen Proving Ground, Md. 
creek. A report by EAI Corporation (1989) included a list of 29 potentially contaminated buildings. Sixteen of the buildings contain known contaminants, nine buildings contain unknown contaminants, and four of the buildings are potentially clean. The EAI report recommended that a sampling and monitoring program be established to verify contamination levels in and around each building. Thirteen of the potentially contaminated buildings, including Building E5282 (Figure 2), located on the northeast corner of Hoadley and Noble Roads, are in the West Branch of the Canal Creek area and are potential sources of volatile organic compounds. Operations have ceased and the buildings have been abandoned, but processing equipment, sumps, drains, ventilation sy'stems, and underground storage tanks remain. These appurtenances may contain liquid, solid, or vapor contaminants of unknown nature.

Aberdeen Proving Ground is proceeding with a program to decommission the buildings, which will eliminate the actual or potential release of contaminants into the environment of the West Branch of the Canal Creek and other sites within the Edgewood area. Argonne National Laboratory has been assigned the task of developing a plan and scope of work for the proposed decommissioning. Argonne has determined that the first step in this decommissioning process, where it is technically feasible, should be a noninvasive geophysical survey around building exteriors (see Figure 3 for the boundaries of the study area for Building E5282).

\subsection{History of Building E5282}

According to the records examined by the EAI Corporation (1989), construction was begun on Building E5282 in 1942, and it was operated as an incendiary warehouse through 1947. The building is constructed on a concrete floor and foundation measuring $57 \mathrm{ft} \times 58 \mathrm{ft}$. The walls are composed of concrete and wood, and the roof consists of rolled metal. After World War II, the building was used as a dry and grind facility for hexachlorethane (HC) smoke munitions. During the years of 1965 through 1976, it was used by the research and development community for a wide variety of operations dealing with agents $\mathrm{HC}$, o-chlorobenzylidene malononitrile (CS), chloroacetophenone $(\mathrm{CN})$, 10-chloro-5,10, hydrophenarazine (DM), 3-quinuclidinyl benzilate (BZ), cyanogen chloride $(\mathrm{CK})$, and mustard $(\mathrm{H})$. Operations involving agents $\mathrm{CK}$ and $\mathrm{H}$ are known to have occurred on the basis of information from personal interviews that were conducted by the Director of Safety at APG. No evidence to support CK or H operations in Building E5282 was discovered by the record-search team. A nonsparking floor was put into place in 1965, and restructuring of the building to its present configuration occurred in 1969. The date of building closure is not known, although it was used through 1975.

The drainage system for the building consists of the following lines and sumps: (1) a 4-in. sanitary drainage line; (2) three main toxic lines leading from the building, one from the north side and two from the south side; and (3) four sumps, each having a detox storage tank of 2000-gal capacity. Each detox tank has a 2 -in. polyvinyl chloride vent attached to the building. 


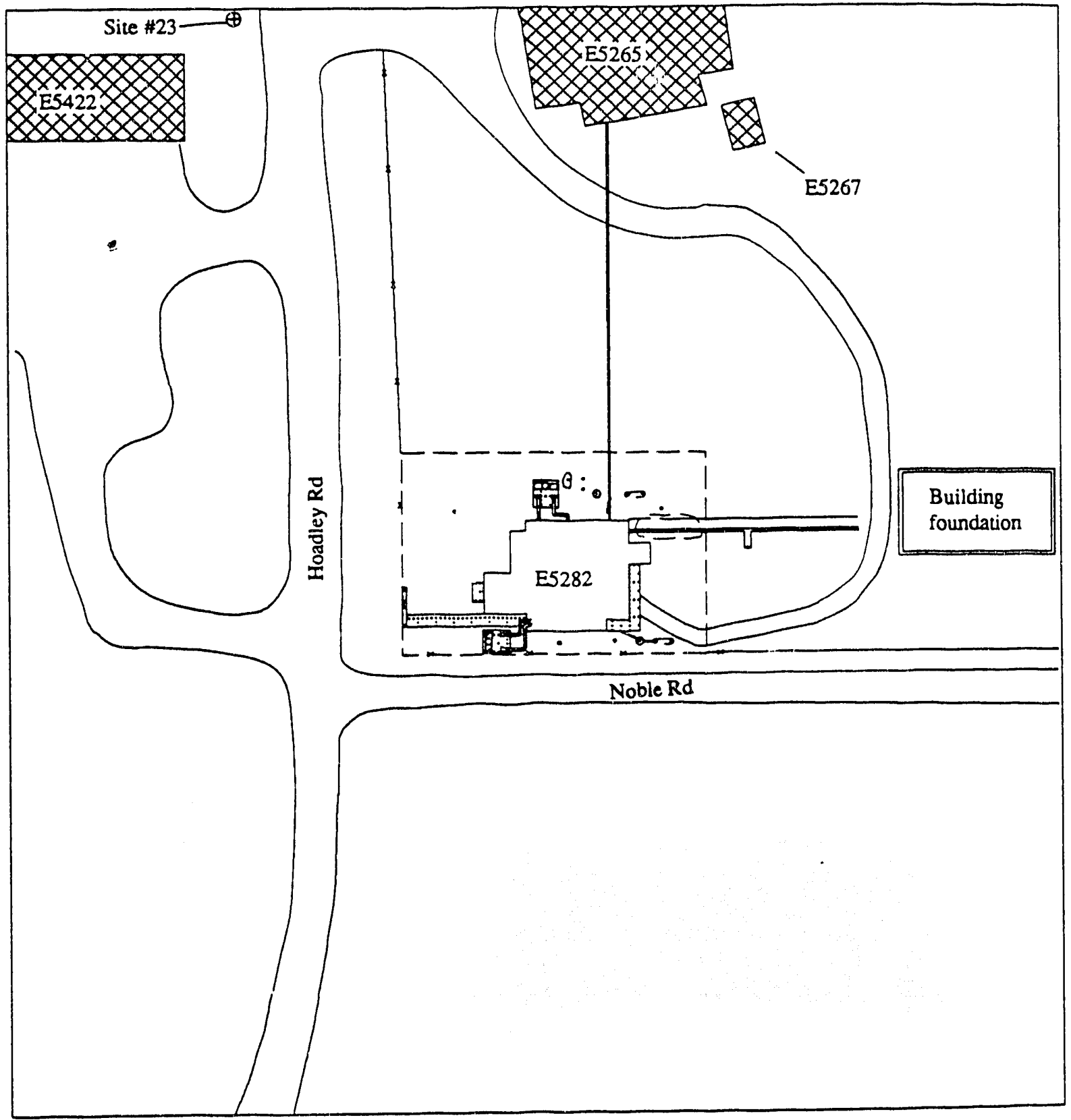

EXPLANATION

28 Adjacent building

Concrete

$\Gamma \quad$ Measured grid

L_ boundary

$\checkmark \quad$ Metal pipe with support poles

$-x-x \quad$ Fence

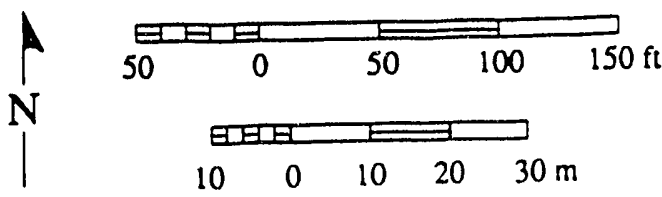

FIGURE 2 General Location Map of Building E5282 


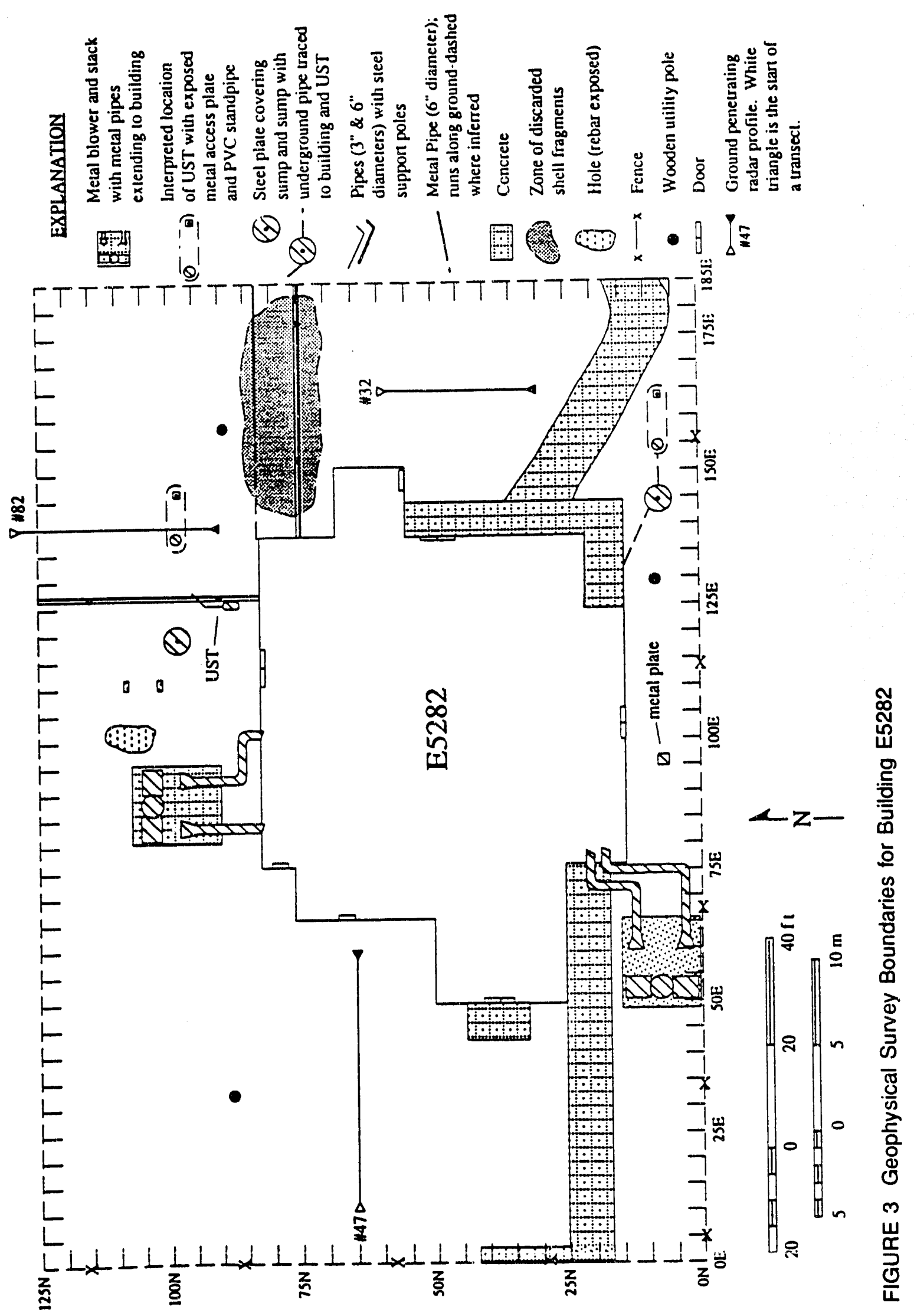




\subsection{Site Reconnaissance}

The geophysical survey program design for Building E5282 is based upon results from a similar study completed between April 8 and April 19, 1991, for Building E5032 (McGinnis and Miller 1991), which is also located in the Canal Creek area (Figure 1). The initial evaluation was further enhanced by a visit to the site in November 1991. The site is accessible on the west, north, and east sides of the building, but access on the south side is restricted by the proximity the chain-link security fence and other aboveground structures.

In addition to surface conditions at the site, subsurface characteristics were considered in planning the geophysical surveying:

1. Surficial sediments consist of estuarine silts, sands, and clays that have intermediate resistivities and are nonmagnetic. The underlying soil properties are expected to vary both horizontally and vertically in the proximity of the site, depending on naturally occurring conditions and on the presence of building excavations and operations.

2. Buildings and other attributes of the Edgewood section of Aberdeen, such as radio and radar transmissions, will contribute to interference of magnetic and electrical fields and will cause electromagnetic surveying (an easily applied, low-cost method that is frequently used to identify buried conductive objects) to be generally inapplicable (AEHA 1989).

3. Multiple sources, such as iron-rich magnetized objects, nonmagnetic objects, subsurface channels containing contaminants, and plumes of contaminants of variable resistivity, may be present in the subsurface.

Multiple working technologies were utilized in the program design to mitigate interference and to either directly derect: or provide inferential data on subsurface characteristics.

\subsection{Geology and Physiographic Setting}

The site is contained in the topographically low and flat terrain of the Coastal Plain physiographic province. The Canal Creek area is underlain by alluvial and estuarine sands, silts, and clays. A thin veneer of sediments of the Talbot Formation of Pleistocene age overlies unconsolidated sediments of the Potomac Group of Cretaceous age (Oliveros and Gernhardt 1989). The water table is less than $10 \mathrm{ft}$ from the surface, and groundwater contains measurable levels of contaminants (USGS 1992). 
Lithologies at the site were determined from the sample study of a borehole (site No. 23) drilled approximately $300 \mathrm{ft}$ northwest of Building E5282 (see Figure 2). The descriptive log given in Table 1 was part of a hydrogeologic study of the Canal Creek area performed by the U.S. Geological Survey (Oliveros and Gernhardt 1989). Facies represented include soils and a clayey fill material to a depth of about $7 \mathrm{ft}$, followed by thin beds of varying stratigraphy, consisting primarily of silty sands and clays to a depth of $14 \mathrm{ft}$. The greatest thickness (15.3 ft) of a single unit was a clean sand at a depth of 14 to $29.3 \mathrm{ft}$. This sand is recognized as the top of the Surficial Aquifer (USGS 1992).

Building E5282 is located near the southern end of the area of study, which includes other buildings not part of the su vey. Initial construction probably involved considerable amounts of cxcavation and use of fill material, so most of the shallow sediment at the site is reworked.

\subsection{Surveys}

The geophysical phase of the building decommissioning program at Building E5282 was carried out as planned during the period April 6 to May 8, 1992. Geophysical measurements conformed to the work plan (McGinnis et al. 1992), which called for magnetics, groundpenetrating radar (GPR), and horizontal direct-current electrical resistivity (DCER) surveys. An

TABLE 1 Lithologic Log of Borehole at Site No. 23

\begin{tabular}{|c|c|c|}
\hline Description ${ }^{\mathbf{a}}$ & $\begin{array}{l}\text { Depth } \\
(\mathrm{ft})\end{array}$ & $\begin{array}{l}\text { Thickness } \\
\qquad(f t)\end{array}$ \\
\hline Soil, brown; with roots & 0.4 & 0.4 \\
\hline Clayey fill material, orange-brown; with asphalt and wood & 7.8 & 7.4 \\
\hline Sand, clayey, orange to $\tan ,[\mathrm{mL}]$ & 10.3 & 2.5 \\
\hline $\begin{array}{l}\text { Clay, silty, white, friable, micaceous; with abundant small } \\
\text { red-purple concretions }\end{array}$ & 11.1 & 0.8 \\
\hline $\begin{array}{l}\text { Sand, silty, multicolored, [mL-mU]; with small lenses of white } \\
\text { clay and small purple concretions }\end{array}$ & 14.0 & 2.9 \\
\hline $\begin{array}{l}\text { Sand, tan, wet, clean, [mL]; with some orange staining and } \\
\text { lenses of clayey silt near bottom }\end{array}$ & 29.3 & 15.3 \\
\hline $\begin{array}{l}\text { Sand, clayey, light gray to orange, [fL-fU]; with small, pink, } \\
\text { silty clay lenses and purple concretions }\end{array}$ & 34.0 & 4.7 \\
\hline $\begin{array}{l}\text { Sand, pinkish-brown, poorly sorted [fU-mU]; with green and } \\
\text { ochre bands, and thin lenses of white silty clay }\end{array}$ & 39.0 & 5.0 \\
\hline
\end{tabular}

a Codes enclosed in brackets at selected horizons refer to color designations as specified in the Munsell Soil Color Charts (1975).

Source: Oliveros and Gernhardt (1989). 
addition to the plan was the use of a magnetic gradiometer/metal detector to ensure detection of anomalies between survey profiles and grid stations. Seismic imaging information was not required at the site. Each technique had its own specific objectives:

- Gradiometer/metal detector sweep - to provide a rapid, $100 \%$ sweep of the site;

- Magnetometer measurements - to determine the location of such buried, ironrich objects as tanks, pipes, debris, etc.;

- Horizontal DCER survey - to establish the regional conductive nature of the subsurface and to identify contaminant plumes to depths of approximately $10 \mathrm{ft}$; and

- Ground-penetrating radar survey - to determine the geometry of, and to find the approximate depth to, buried objects.

The following data were acquired during field operations: (1) nonpermanent ground markings of magnetic objects, (2) 1,805 magnetic observations, (3) 406 horizontal DCER observations, and (4) 5,605 (linear) ft of GPR profile along 84 lines. Field operations required a total of two days for a four-person team. On-site personal computers (both notebook and desktop), interactive software, field equipment designed specifically for Aberdeen, and an allterrain vehicle were used to expedite data acquisition and processing.

\subsection{Survey Grid and Locations of Observations}

Prior to geophysical surveying, wooden stakes were placed at the site corners to mark the area to be surveyed so that its sides were approximately parallel to the sides of the building. Geophysical measurements south of the building were restricted by the proximity to the chain-link security fence and other aboveground structures. Grid spacing was at 5 - $\mathrm{ft}$ intervals, with the zero coordinate located at the southwest corner of the surveyed area. Positive numbers are measured north and east from the zero coordinate, whereas negative coordinates are measured south and west. The building is not perfectly aligned north-south and east-west. 


\section{Instrumentation}

\subsection{Magnetic Gradiometer and Cable Locator}

The Schonstedt MAC-51B magnetic gradiometer and cable locator is a dual-mode instrument designed for detecting shallow buried iron and steel objects and tracing underground cables and pipes. The system consists of a transmitter and a dual-function receiver designed to detect anomalous magnetic gradients.

Maps or models are not constructed from observations made with this instrument because it is not a calibrated system. The MAC-51B is an audio device used only for rapid detection of magnetic materials for further analysis with complementary instrumentation. Anomalies are identified by changes in sound amplitude and frequency and are marked on the ground surface prior to the initiation of other surveys. If anomalies detected with the MAC-51B cannot be verified with the magnetometer (see section on magnetometer), the anomaly is assumed to be insignificant.

Application of the MAC-51B in its receiver mode was the first geophysical operation following establishment of survey linits. A qualitative description of the site with $100 \%$ ground coverage is achieved using the gradiometer, whereas the results obtained with other techniques, although more quantitative, are spatially limited to single-point, survey-grid observations or to continuous readings along spaced profiles.

\subsection{Magnetometer/Gradiometer}

Magnetics is the best technique for identifying such buried magnetized objects as tanks, drums, and small iron-rich debris. The EDA OMNI IV magnetometer/gradiometer is a total-field, proton-precession, microprocessor-based instrument that can also measure magnetic gradients. Internal software permits down-loading directly into an on-site computer.

Total-field magnetic observations were made at 5 - $\mathrm{ft}$ and smaller intervals along profiles, yielding a grid of data that was contoured using SURFER V. 4.0 software by Golden, Inc. (1991), to identify potential sources of contaminants and to distinguish them from background. The SURFER software was incorpcrated into the field acquisition procedure, so that daily map outputs were available for observation and interpretation.

The earth's magnetic field is reasonably well-known at a given time and place, although small changes in the field occur continuously, with larger changes occurring during magnetic storms. To adjust for field changes, the instrument has internal calibration to correct observations made at cross lines and base stations. Repeat readings were used to correct data for diurnal field fluctuations. 


\subsection{Direct-Current Electrical Resistivity Meter}

Data on the electrical properties of soils at APG may permit detection of abnormally conductive or nonconductive liquid or solid contaminants. Most of the electrical properties of sedimentary materials are a product of the chemistry of interstitial fluids. Consequently, resistivity data can be diagnostic and complement magnetic and radar measurements. Direct-current electrical resisti iy measurements have been incorporated into the APG study to take the place of conductivity measurements typically made for investigations of this type using electromagnetic methods. Electromagnetic methods could not be used because of previously reported interference problems (AEHA 1989).

Resistivity equipment used on the Aberdeen project consisted of an ABEM Terrameter and Booster, model SAS $300 \mathrm{C}$, that utilized a variety of electrode configurations. A modified, eightelectrode Wenner array was the configuration selected, and it was towed behind an all-terrain vehicle. Profiles were coincident with GPR and magnetic lines, and data were recorded at 5-ft intervals along the lines. Consistency of repeat observations over a test profile and over known electrical anomalies provided assurance of relative data quality and variations. Data were contoured using SURFER software as described in the magnetics section.

Electrical depth-sounding curves using a Schlumberger electrode array were also determined in the Canal Creek area to add a three-dimensional view to horizontal mapping. Each sounding curve was interpreted using the RESIX PLUS software package written by Interpex (1988). Resistivities of undisturbed soils were comparable with those observed at Building E5032, which averaged $60 \Omega-\mathrm{m}^{*}$ (See Appendix A for further information.)

\subsection{Ground-Penetrating Radar System}

Ground-penetrating radar surveying was accomplished using a Geophysical Survey Systems, Inc. (GSSI), model SIR-3 radar connected to a transceiver with a cable approximately $300 \mathrm{ft}$ long. Data were recorded on a digital audio tape to permit playback and computer processing. The control unit/graphic recorder was located in the transport vehicle. An IBMcompatible processing computer was located in a field office, so that the radar operator could down-load, check data-tape quality, and do preliminary processing after a day's run. Radan I computer software written by GSSI was used for processing the GPR data.

Wave-velocity characteristics of materials to be found at the Aberdeen/Edgewood area were derived from known positions of buried objects. Internal calibration was run at least twice each day to ensure that the graphic record of the range setting was consistent. Studies conducted during

\footnotetext{
* Resistivity data acquisition and processing were done using the metric system of measurement. To convert from meters to feet, multiply values given in meters by 3.28 .
} 
the 1991 field season suggest wave velocities of $6-7 \times 10^{-9} \mathrm{~s} / \mathrm{ft}$ for near-surface sediment at Aberdeen; however, conditions vary with the heterogeneity of the subsurface. Typical wave velocities for different materials are shown in Table 2.

Ground-penetrating radar is probably the best method available to determine depth and geometry of objects buried near the surface. The weakness of the method is its limited depth of exploration due to wavepropagating constrain's imposed by the electrical properties of soils. The maximum depth of penetration with GPR at Building E5282 was approximately $8 \mathrm{ft}$ below the ground surface.
TABLE 2 Approximate Two-Way Travel Times for Various Materials

\begin{tabular}{lc} 
& $\begin{array}{c}\text { Two-Way } \\
\text { Material }\end{array}$ \\
& $\begin{array}{c}\text { Travel Time } \\
\left(10^{-9} \mathrm{~s} / \mathrm{ft}\right)\end{array}$ \\
\hline & \\
Air & 2 \\
Fresh water & 18 \\
Sea water & 18 \\
Sand (dry) & 4.5 \\
Sand (saturated) & 11 \\
Silt (saturated) & 6 \\
Clay (saturated) & 6 \\
Dry, sandy, coastal land & 6 \\
Marshy forested land & 7 \\
Rich agricultural land & 8. \\
Fresh-water ice & 4 \\
Granite (dry) & 4.5 \\
Limestone (dry) & 5 \\
Concrete & 5 \\
Asphalt & $4-5$ \\
\hline
\end{tabular}

Source: Geophysical Survey Systems, Inc. (1987). 


\section{Geophysical Measurements and Surveys}

\subsection{Magnetometer Measurements}

Total magnetic-field observations were made at 1805 stations for use in construction of the magnetic map shown in Figure 4. Station spacing was normally $5 \mathrm{ft}$; however, where the presurvey scan identified anomalous zones, stations were read at intervals as small as $1 \mathrm{ft}$. Readings were not made within $5 \mathrm{ft}$ of the security fence to minimize interference with the magnetic observations. Peaks and troughs of positive and negative anomalies were truncated to permit a clearly displayed visual representation of the magnetic field. Thus, anomaly interiors are depicted as "white-outs". Because of surface interference caused by pipes, metal racks, exhaust stacks, and fences, considerable caution should be observed when viewing anomalies on the north, east, and south. The fence at the far west end of the survey site is not associated with an anomaly of high amplitude, although a north-south lineament on the west is probably fence-related.

In general, the west and northwest margins of the building, essentially that area outlined by a low topographic terrace composed of fill material, are underlain by multiple magnetic sources scattered within the building fill. Anomalies produced by these sources are, for the most part, defined by one or two magnetic stations. One north-south, elongated, multistation anomaly (survey coordinates $45 \mathrm{E}, 70 \mathrm{~N}$ ) is centered approximately $20-25 \mathrm{ft}$ west of Building E5282. This anomaly has a size and shape consistent with that of an underground storage tank (UST); however, it is not associated with such surface features as vents, fill pipes, or mounds that would support a UST interpretation. The anomaly may be caused by buried pipe oriented in a north-south direction and by clusters of magnetic sources that appear as a single magnetic anomaly.

A north-south elongated anomaly, centered at survey coordinates $100 \mathrm{~N}, 105 \mathrm{E}$ (approximately $20 \mathrm{ft}$ north of the building) also has the size and shape of a UST-derived magnetic anomaly, but this anomaly also is not associated with such expected surface features as vents, fill pipes, or access plates. Rebar and concrete fragments exposed in a shallow pit $5 \mathrm{ft}$ west of this anomaly suggest an alternative source.

A magnetic high centered at survey coordinates $95 \mathrm{~N}, 135 \mathrm{E}$ is caused by a UST that is oriented with its long axis east-west. The center of this magnetic high is offset approximately $7 \mathrm{ft}$ west of the presumed center of the UST. Surface features such as vents and fill pipes support this UST interpretation, as does GPR profile data.

A large and complex anomaly, with an amplitude of several thousand gammas, is centered approximately $25 \mathrm{ft}$ east of the eastern-most projection of the building. This anomaly is caused by unexploded-ordnance fragments that were scattered at the surface and by aboveground pipes and the structural braces supporting these pipes. If any subsurface sources were present, they would be masked by this dominant anomaly. 


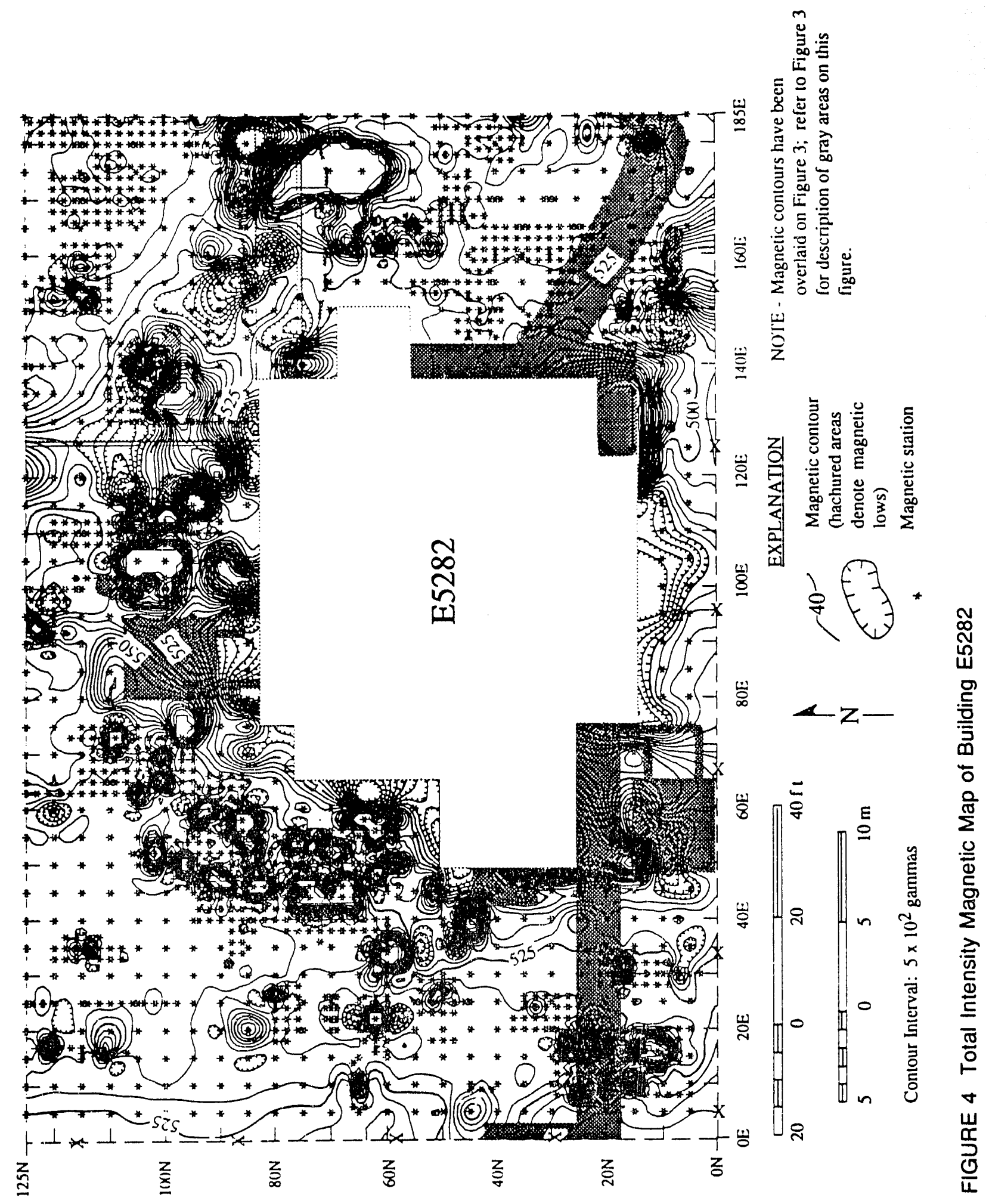


Six smaller anomalies located near the southwest corner of the surveyed area are probably caused by a drainage pipe oriented north-south that underlays a cement sidewalk. A large anomaly near the southwest corner of the building is produced by an aboveground complex of fans, blowers, exhaust pipes, and associated plumbing.

Three isolated $r$ omalies are observed near the southeast corner of the surveyed area. Of these, the east-west elongated anomaly centered at $156 \mathrm{E}, 7 \mathrm{~N}$ is caused by a UST. Vents, fill pipes, and steel access plates located on the anomaly support this interpretation.

\subsection{Direct-Current Electrical Resistivity Measurements}

The resuits of the DCER survey are illustrated in Figure 5. The electrode spacing was $2 \mathrm{~m}$, a configuration that provides an average resistivity for materials lying between the surface and a depth of about $3 \mathrm{~m}$. As known from the borehole log at site No. 23, which was shown in Table 1, these materials would include fill; an orange-brown material with asphalt and wood; and most of the thickness of the Upper Confining Unit (Oliveros and Gernhardt 1989), which is a silty clay.

From previous work (McGinnis and Miller 1991), background resistivities for these finegrained, organic-rich, clayey materials were found to range from 50 to $150 \Omega$-m. Electrical depthsounding curves collected for background in the Edgewood area indicate that resistivity values normally decrease with depth, probably due to increasing saturation and concentrations of dissolved solids. Where anomalous materials are present, this generalization is not valid. Measurements made along an east-west line at an electrical depth-sounding station centered at survey coordinates $195 \mathrm{E}, 140 \mathrm{~N}$, with electrodes expanded outward to a maximum spacing $(\mathrm{AB} / 2)$ of $60 \mathrm{~m}$, are given in Appendix A. Inversion of the electrical depth-sounding curve shown in Appendix A for Building E5282 results in an interpreted earth-model having surficial resistivities of $108 \Omega-\mathrm{m}$ in the upper $40 \mathrm{~cm}$. From $40 \mathrm{~cm}$ to $4.5 \mathrm{~m}$, about the combined thickness of fill and the Upper Confining Layer, resistivities average $244 \Omega-\mathrm{m}$. Resistivities drop back to $95 \Omega-\mathrm{m}$ below $4.5 \mathrm{~m}$ depth.

Apparent resistivity values in the surveyed area of Building E5282, acquired using horizontal profiling techniques, range from a minimum of $80 \Omega$-m near the north central wall of the building to a high value of $600 \Omega-\mathrm{m}$ centered about $25 \mathrm{ft}$ east of the building. The high resistivities observed at this location might be attributed to the presence of asphalt and wood (known from the drillers report) or gravel and unreinforced concrete. Another cause may be the presence of nonconductive liquids, which are known to be in the area (Figure 106, USGS 1992). However, the causes cannot be known with certainty without subsurface sampling.

The extremely high resistivity values observed to the east of the building were located in an area where gravel, cobbles, and rusted metallic debris (unexploded ordnance fragments) were 


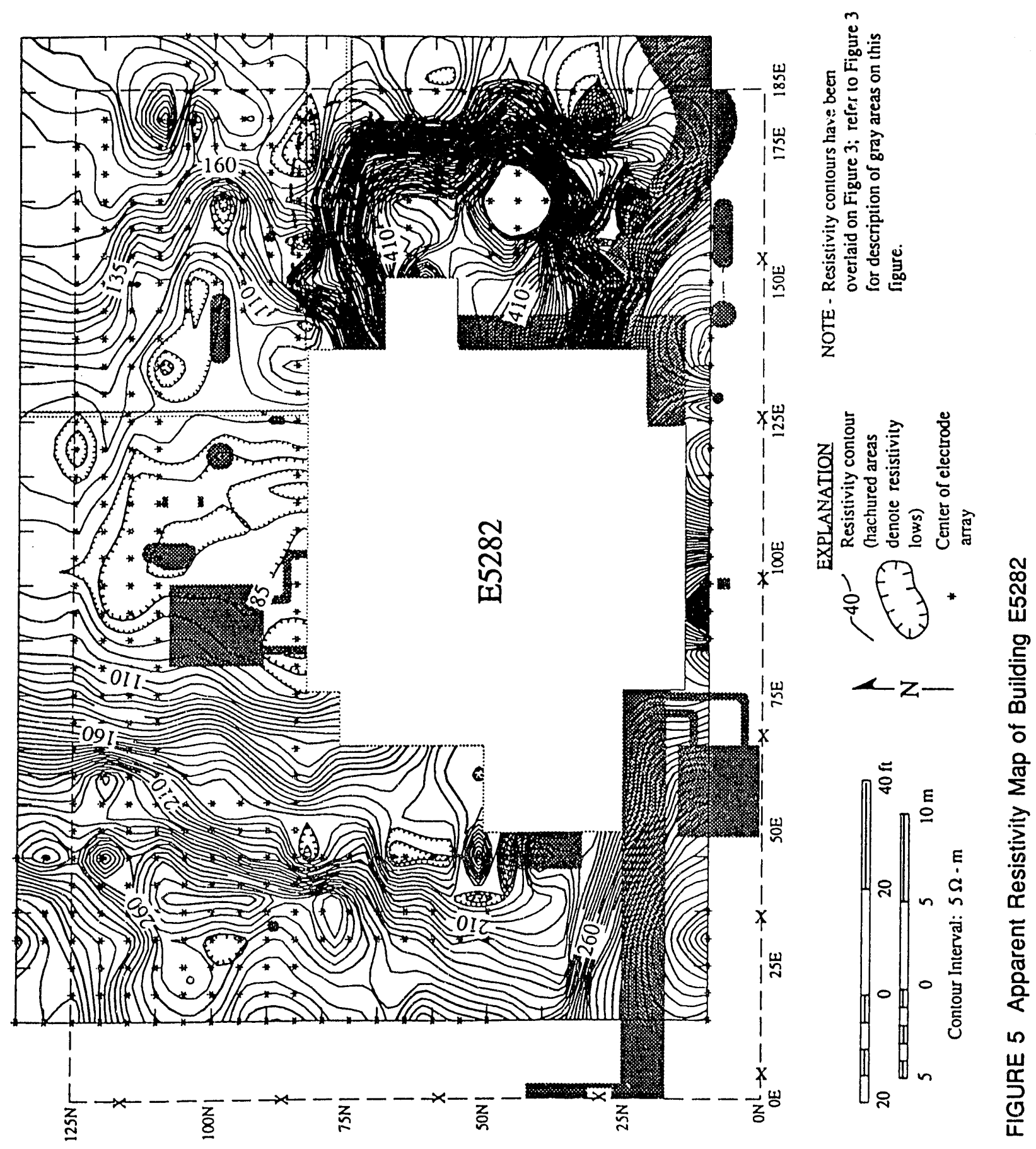




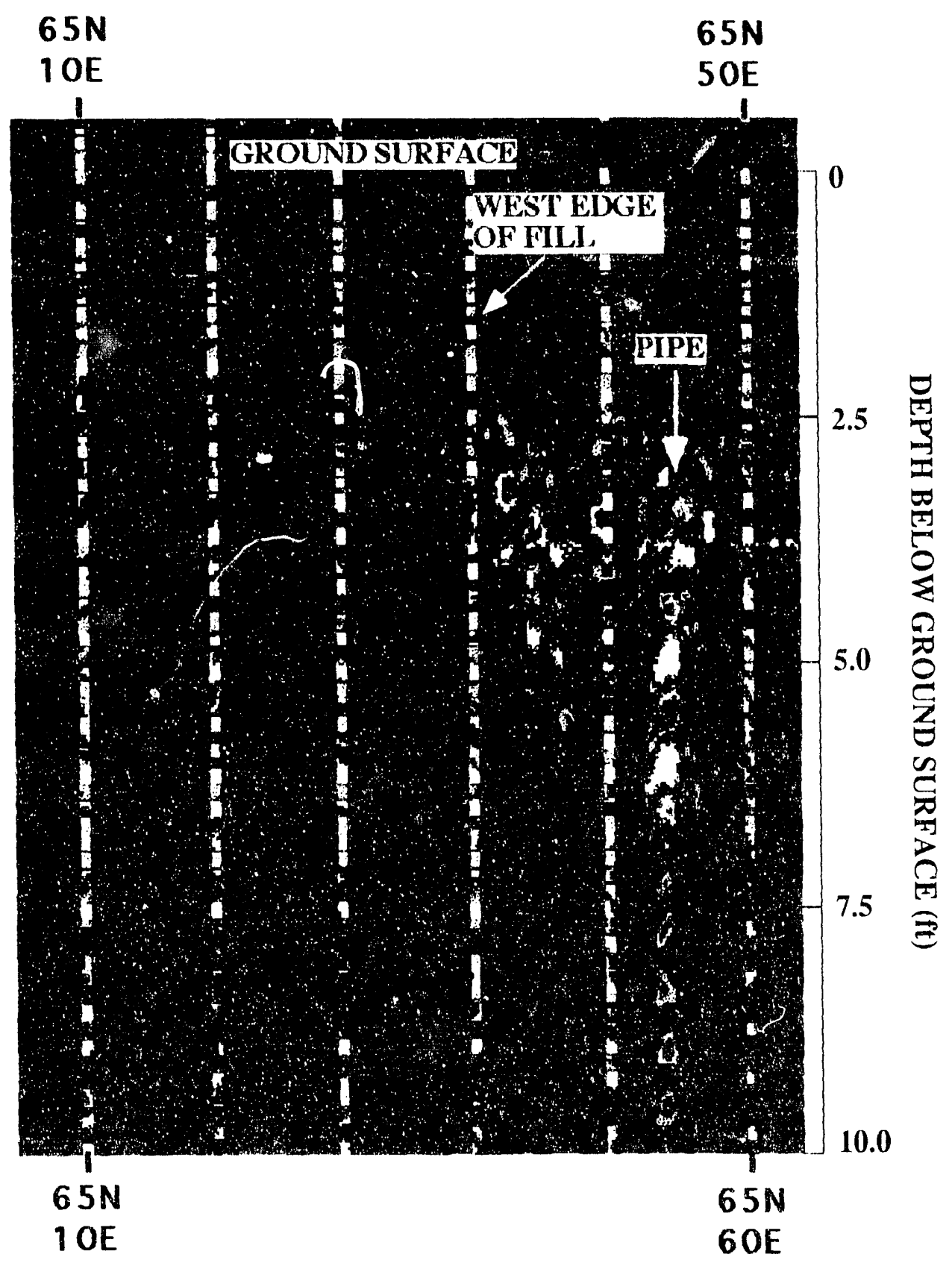

FIGURE 6 West-East Ground-Penetrating Radar Profile for the Area West of Building E5282 (The location of this profile is shown in Figure 3 as line No. 47.) 
found lying at the surface. Dry, shallow, construction fill material may be part of the cause of these extremely high resistivities, although the fill material west of the building is associated with relatively more conductive and magnetic zones.

\subsection{Ground-Penetrating Radar Measurements}

Ground-penetrating radar measurements around the building perimeter were made at 5- $\mathrm{ft}$ intervals over $5,605 \mathrm{ft}$ of traverse along 84 individual profiles, coincident with magnetic and resistivity profiles. The lines are numbered in sequence and are listed in Appendix B, along with the beginning and ending positions relative to the grid survey. Prior to running the production lines for the survey, replicate runs were made over the same line to determine which of the three transceivers - the $80-, 300-$, or $500-\mathrm{MHz}$ antenna - was best suited to study the terrain surrounding the site. The transceiver providing the best penetration and resolution of buried objects was the $300-\mathrm{MHz}$ unit. Different range settings were also tested over the same transect to determine the optimum resolution and depth of penetration. A range setting of $90 \mathrm{~ns}$ was used for the entire survey at scan rates of both 16 and 32 scans/s. However, some additional profiles were collected at a range setting of $70 \mathrm{~ns}$ over selected anomalies around Building E5282. Antennas were pulled by hand at approximately $3 \mathrm{ft} / \mathrm{s}$.

Most of the profiling was done in the areas north, east, and west of the building; some lines were run in the narrow space between the building and the fence to the south. Perimeter profiles were designed to detect buried objects extending radially from the building. Figures 6,7 , and 8 show the GPR profiles. The vertical scale is shown on the right side of the profile, whereas lines are marked at $10-\mathrm{ft}$ intervals for the horizontal scale.

Without verification by another technique or by passing the antenna over a known buried object, characteristics of radar anomalies may only be inferred. However, where GPR anomalies coincide with magnetometer or electrical anomalies, a more specific interpretation of the radar anomaly is possible.

Good penetration was observed over most of the site, with resolution down to about $8 \mathrm{ft}$ below the ground surface. The major findings of the GPR survey around Building 25282 are as follows:

1. Building E5282 appears to be built over 2-3 $\mathrm{ft}$ of engineered fill that contains scattered metallic debris. A GPR profile oriented west-east (Figure 6) shows the western edge of this fill at approximately $40 \mathrm{E}$ on the west side of the building. Figure 6 also shows a small diameter pipe at a depth of approximately $3 \mathrm{ft}$ that is oriented north-south at 53E. This pipe is seen in other GPR profiles from $65 \mathrm{~N}$ to $90 \mathrm{~N}$ and corresponds with a magnetic anomaly shown in Figure 4. The determination of the depth of any object in a GPR profile is a rough approximation unless the electrical properties of the soils at each profile are 


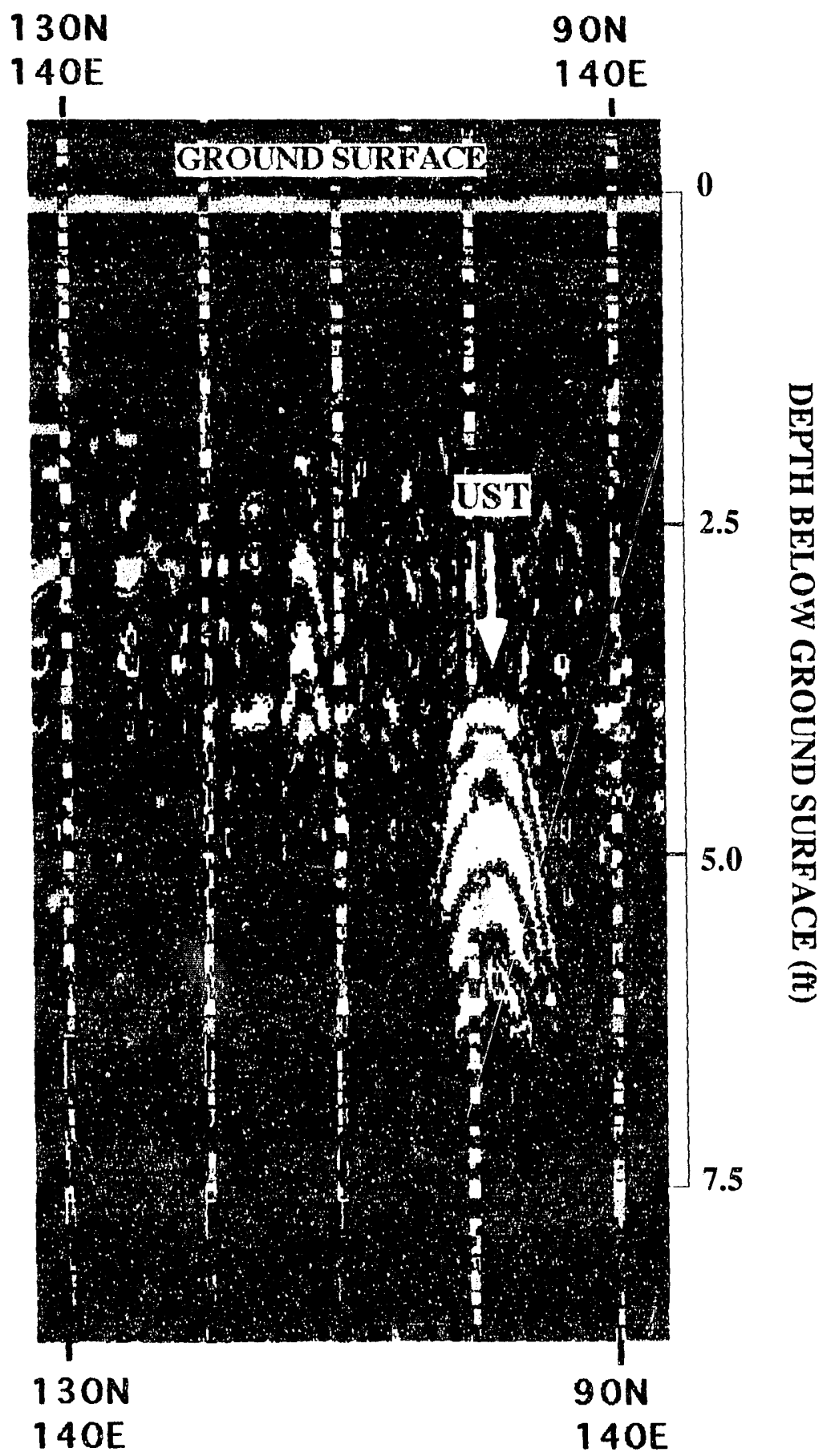

FIGURE 7 North-South Ground-Penetrating Radar Profile for the Area North of Building E5282 (The location of this profile is shown in Figure 3 as line No. 82.) 
known. The radar signal is unable to penetrate below the metal object, and the reflectors below the first reflector are due to ringing multiples.

2. The GPR profiles collected to the north and east of Building E5282 show many shallow metallic objects in the upper 1-2 ft. In areas where this metallic debris is very concentrated, the radar signal is unable to penetrate below the debris. This is especially trie in the area east of the northeast corner of the building, where unexploded ordnance was found at the surface. The debris to the north of the building does not appe: $;$ to extend beyond a distance of $30 \mathrm{ft}$.

3. The presence of the two USTs was confirmed with the GPR. The two tanks are centered at coordinates $98 \mathrm{~N}, 142 \mathrm{E}$ and $8 \mathrm{~N}, 158 \mathrm{E}$. Both of the tanks are oriented east-west, and each is approximately $12 \mathrm{ft}$ long. Figure 7 clearly shows the UST north of the building at coordinates 98N,142E. The GPR signature of the UST southeast of the building is nearly identical. The profiles collected over the USTs show that both are buried at depths of approximately $3.5 \mathrm{ft}$ and confirm that each tank is connected by a pipe to a round sump located to its west. The GPR profiles also revealed a pipe that extends from the sump at the southeast corner toward Building E5282.

4. GPR line No. 32, which wis collected from the north to the south along $165 \mathrm{E}$, shows a prominent flat-lying reflector that starts at $63 \mathrm{~N}$ and extends to $35 \mathrm{~N}$ (see Figure 8). This feature is also visible on east-west GPR lines. The feature tends to lose its flatness and becomes much more intermittent toward the north. It is characterized by two reflectors, one at $2.5 \mathrm{ft}$ and a second, more prominent one, at $5.0 \mathrm{ft}$ below the ground surface. This anomaly could be produced by such buried debris as concrete without steel reinforcement; by layered, coarse fill; or by a highly reflective liquid. 


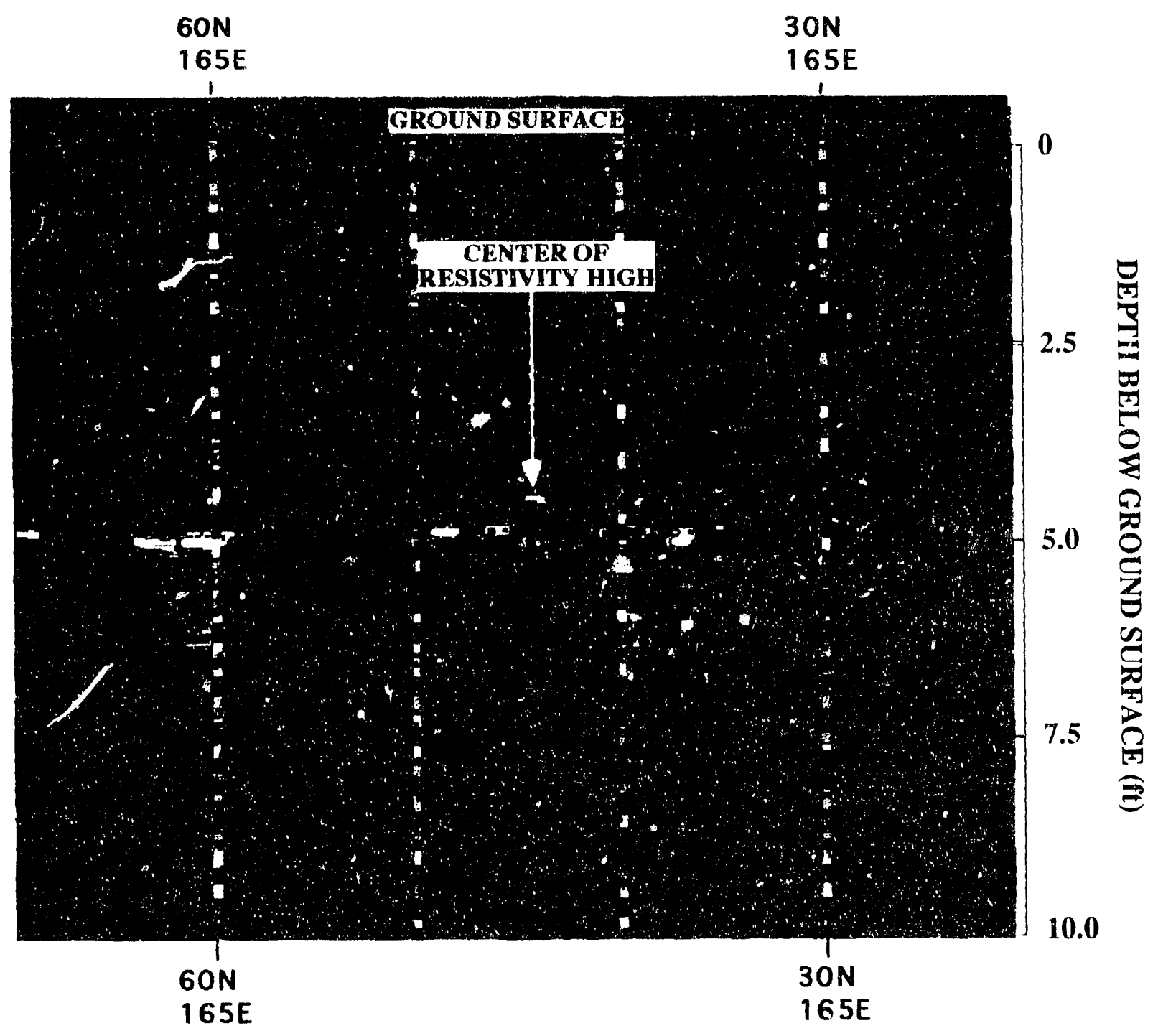

FIGURE 3 North-South Ground-Penetrating Radar Profile for the Area East of

Building E5282 (The location of this profile is shown in Figure 3 as line No. 32.) 


\section{Discussion}

A map combining the magnetic and DCER data is shown in Figure 9. Electrically conductive areas generally conform with positive magnetic anomalies, where both data sets are complete. This relationship is most pronounced west of the building, where electrical gradients outline a bruad cluster of high-intensity magnetic anomalies. Conductive and highly magnetic areas to the north and southeast of the building also have a common source. No resistivity data were acquired in the anomalous magnetic zone in the southwest corner of the surveyed area. The extremely high resistivity region east of the building is not associated with a similar magnetic feature, but does coincide with a strong reflector in the GPR data. A broad magnetic positive north of the resistivity anomaly is caused by aboveground debris and plumbing and is therefore not represented by a coincident electrical anomaly.

The integration of data from all the geophysical measurements performed around Building E5282 further enhances the interpretation. The three GPR profiles (Figures 6, 7, and 8) that show anomalies are supported by both the magnetics and the electrical resistivity data. The GPR anomaly shown in Figure 6 (west side of building) coincides with magnetic anomalies and electrical gradients associated with building fill. The concentration of magnetic anomalies that trend from south to north also coincide with a pipe anomaly seen in several GPR profiles.

The magnetic and GPR data show two large anomalies that are the results of USTs. These USTs are centered at coordinates $98 \mathrm{~N}, 142 \mathrm{E}$ and $8 \mathrm{~N}, 158 \mathrm{E}$. Both of the tanks are oriented eastwest, and each is approximately $12 \mathrm{ft}$ long. The GPR profiles over both tanks show the tops at approximately $3.5 \mathrm{ft}$ below the ground surface. The GPR profiles also showed pipes extending from each tank to round sumps located to the west of each. A pipe that extends from the sump at the southeast corner toward Building E5282 was also revealed. 


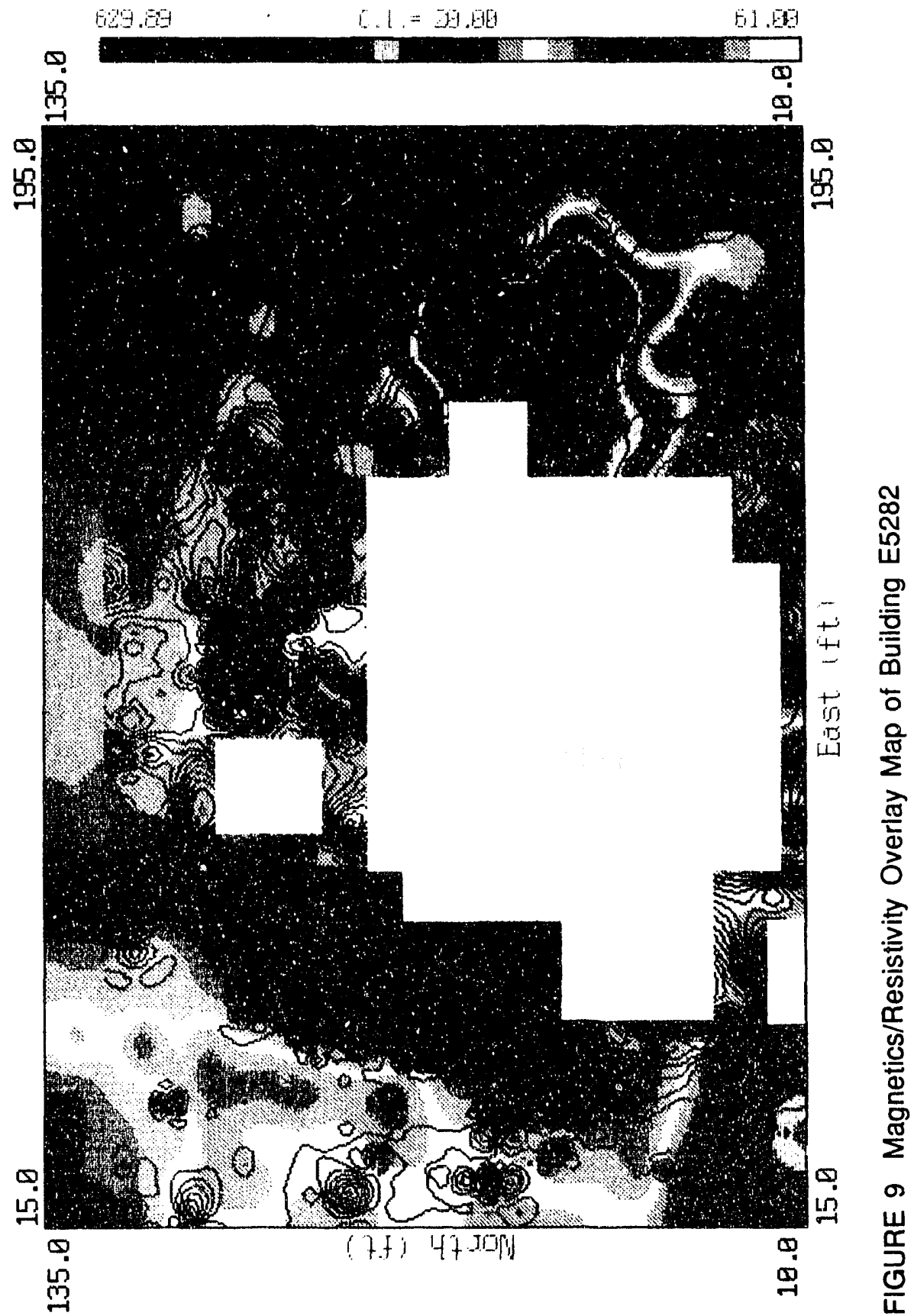




\section{Conclusions}

Specific conclusions drawn from the site surveys of Building E5282 are the following:

1. Isolated magnetic and GPR anomalies west of the building are due to small, scattered, metallic debris that probably poses no environmental hazard.

2. Electrically conductive zones west and north of the building outline areas of increased metallic debris in construction fill.

3. Two underground storage tanks, one near the southeast corner of the building and a second near the northeast corner, are associated with magnetic anomalies and a GPR image.

4. A circular, high-intensity, high-resistivity anomaly measuring about $25 \mathrm{ft}$ in diameter is centered approximately $25 \mathrm{ft}$ east of the building and is in line with east-facing, steel double-doors. The feature spreads out to the north and south away from the building and is not associated with a magnetic anomaly or with any surface feature. GPR imaging in this area indicates a prominent, horizontal reflector lying $5 \mathrm{ft}$ below the surface. The source of the anomaly may be a concrete slab without steel reinforcement; layered, high-resistivity construction fill; or high-resistivity liquid above the water table. 


\section{References}

AEHA: see U.S. Army Environmental Hygiene Agency.

E.AI Corporation, 1989, Historical Records Search and Site Survey of Edgewood Area Buildings, Final Report, prepared for U.S. Army Chemical Research, Development, and Engineering Center, Aberdeen Proving Ground, Md., under contract No. DAA 15-87-D0021.

Geophysical Survey Systems, Inc., 1987, Operations Manual for Subsurface Interface Radar (SIR System-3).

Golden Software, Inc., 1991, Surfer Version 4, Golden, Colo.

Interplex Limited, 1988, RESIX PLUS User's Manual, Golden, Colo.

McGinnis, L.D., and S.F. Miller, 1991, Interim Progress Report - Geophysics: Building E5032 Decommissioning, Aberdeen Proving Ground, report ANL/ESD/TM-20, Argonne National Laboratory, Argonne, Ill.

McGinnis, L.D., S.F. Miller, M.G. McGinnis, and M.D. Thompson, 1992, unpuolished information, Argonne National Laboratory, Argonne, Ill.

Munsell Soil Color Charts, 1975, Macbeth, a division of Kollmorgen Corp., Baltimore, Md.

Oliveros, J.P., and P. Gernhardt, 1989, Hydrogeologic Data for the Canal Creek Area, Aberdeen Proving Ground, Maryland, April 1986-March 1988, U.S. Geological Survey Open-File Report 89-387.

U.S. Army Environmental Hygiene Agency (AEHA), 1989, RCRA Facility Assessment Report, Edgewood Area, Aberdeen Proving Ground, Maryland.

USGS: See U.S. Geological Survey

U.S. Geological Survey, 1992, Contamination of Groundwater, Surface Water, and Soil and Evaluation of Selected Pumpage Scenarios in the Canal Creek Area of Aberdeen Proving Ground, Maryland, draft open-file report. 
Appendix A:

Electrical Depth-Sounding Curves

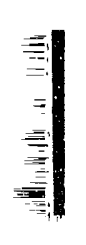




\section{Appendix A: \\ Electrical Depti.-Sounding Curves}

Four Schlumberger electrical depth-soundings near buildings in the Edgewood area provide a depth dimension to resistivities of soils, sediment, and anomalous unidentified materials. Soundings were made near Buildings E5282, E5440, E5481, and E5974. Locations of centers of stations and orientations of electrode arrays are listed in Table A.1, and the curves are shown at the end of Appendix A as Figures A.1-A.4.

Inversion of these curves using the Interpex code, RESIX PLUS (Interpex Limited 1988), indicates that resistivity of dry soils is from 200 to $300 \Omega-\mathrm{m} ;{ }^{*}$ saturated sediments, about $100 \Omega-\mathrm{m}$; saturated, organic-rich sediments, about $200 \Omega-\mathrm{m}$; and anomalous materials range from less than 10 to $10,000 \Omega-m$. Maximum current electrode spacings $(\mathrm{AB} / 2)$ ranged from 40 to $100 \mathrm{~m}$, providing information to depths of about $50 \mathrm{~m}$.

Normal undisturbed curves were observed at Buildings E5282 and E5481. These stations were located in topographically low areas where the water table lies within $3 \mathrm{~m}$ of the surface.

A reasonable interpretation of the curve at Building E5440, which was centered in an open area northeast of the building, is not feasible without more historical information about the site. Former roads, landfills, and other subsurface artifacts could explain the orders of magnitude change in resistivity values from $15 \Omega-\mathrm{m}$ to $10,000 \Omega-\mathrm{m}$ at a depth of $11 \mathrm{~m}$.

TABLE A.1 Location of Centers of Stations and Orientations of Electrode Arrays for Schlumberger Electrical Depth-Soundings at APG

\begin{tabular}{lcc}
\hline \multicolumn{1}{c}{ Station Center } & $\begin{array}{c}\text { Array } \\
\text { Orientation }\end{array}$ & $\begin{array}{c}\text { Maximum } \\
\text { Electrode } \\
\text { Spacing } \\
(\mathrm{m})\end{array}$ \\
\hline Northeast of Building E5282 & E-W & 50 \\
Northeast of Building E5440 & NW-SE & 40 \\
North of Building 5481 & E-W & 80 \\
Northwest of Building E5974 & NW-SE & 100 \\
\hline
\end{tabular}

* Electrical depth-soundings were measured in the unit of ohm-meter. Thus, discussion of electrical depth-soundings in this report gives depths measured in meters. To convert from meters to feet, multiply depths in meters by 3.28 . 
The sounding curve at Building E5974 displays the most unusual surface resistivities. A 2.7-m-thick layer of extraordinarily high resistivity $(3,055 \Omega-\mathrm{m})$ near the surface is underlain by a layer having a higher than normal value $(440 \Omega-\mathrm{m})$ extending to a depth of $50 \mathrm{~m}$. This is underlain by a layer having normal resistivities of $123 \Omega-\mathrm{m}$.

Earth resistivity models calculated from inversion of the sounding curves are shown in Table A.2.

TABLE A.2 Resistivity Models Calculated from Electrical Depth Soundings

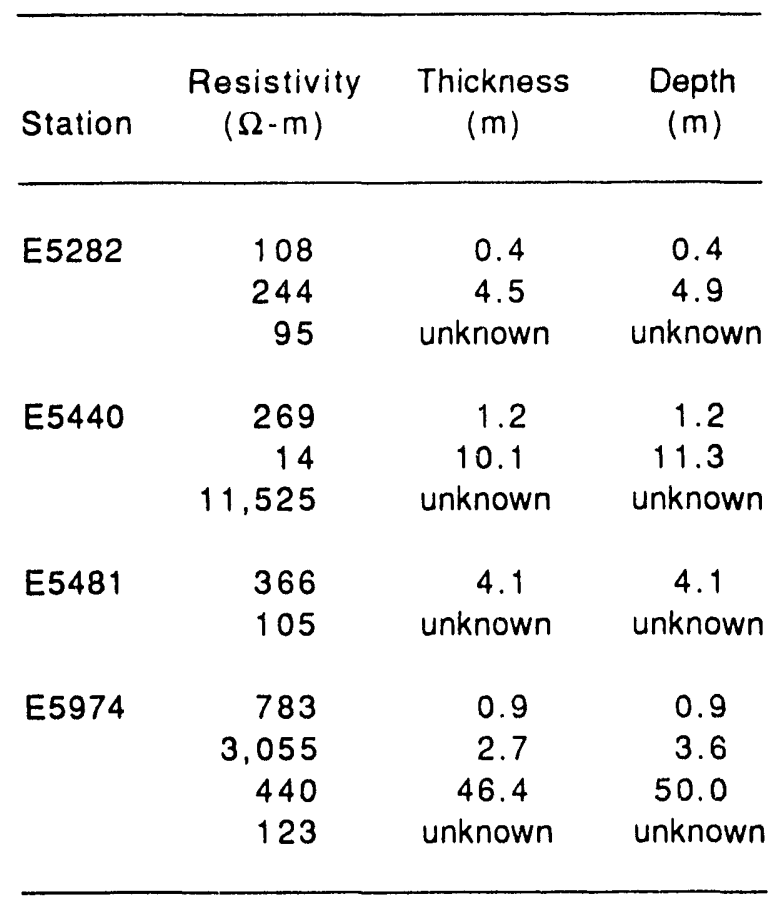



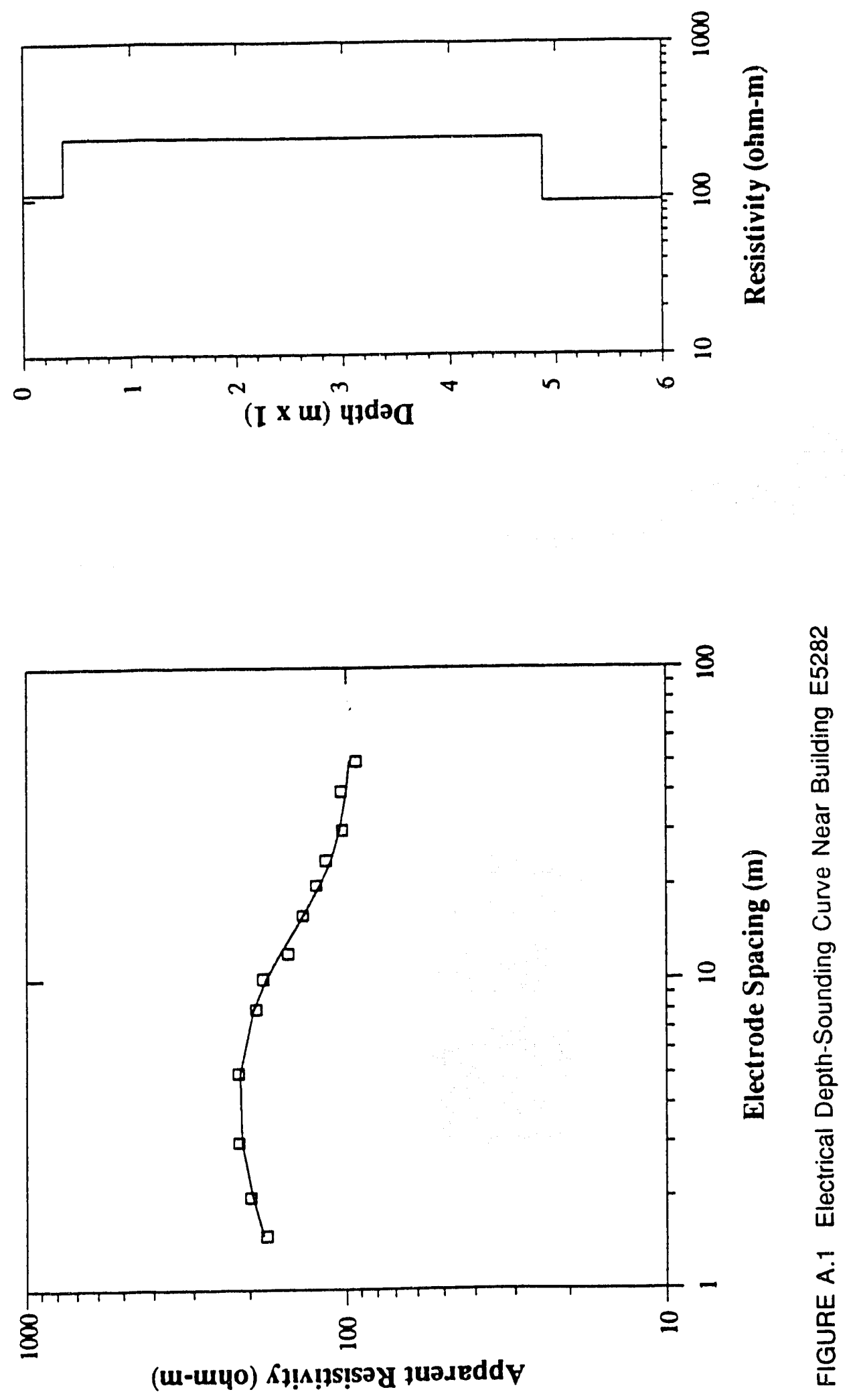


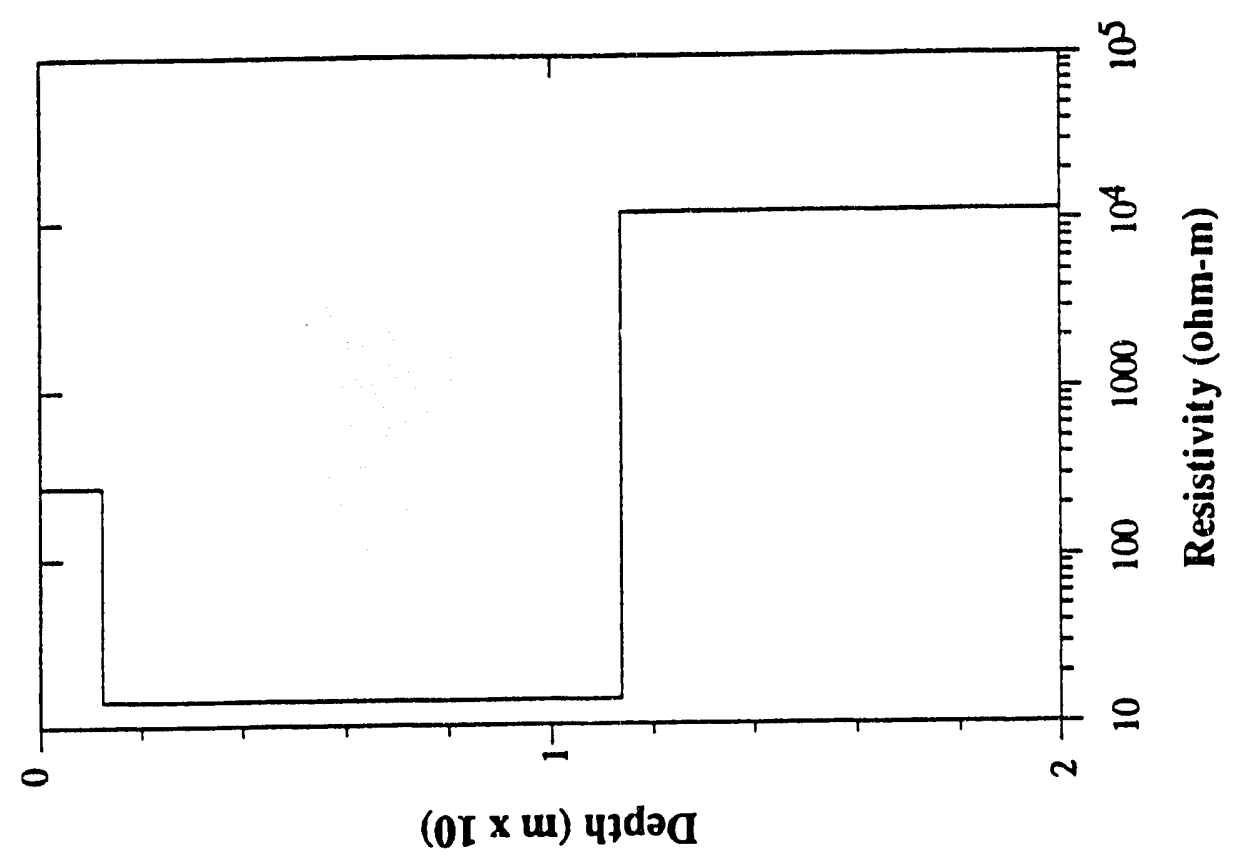

운

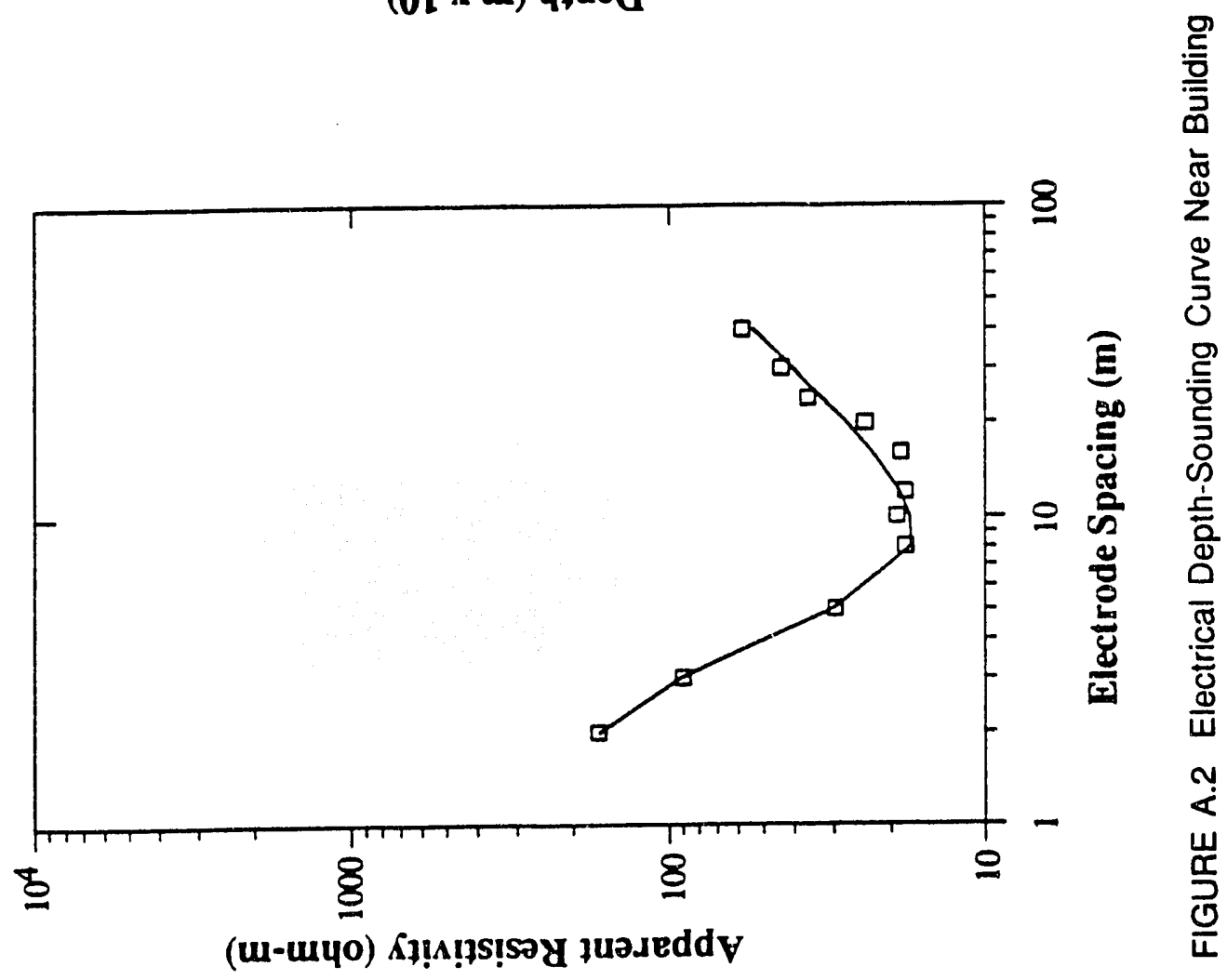




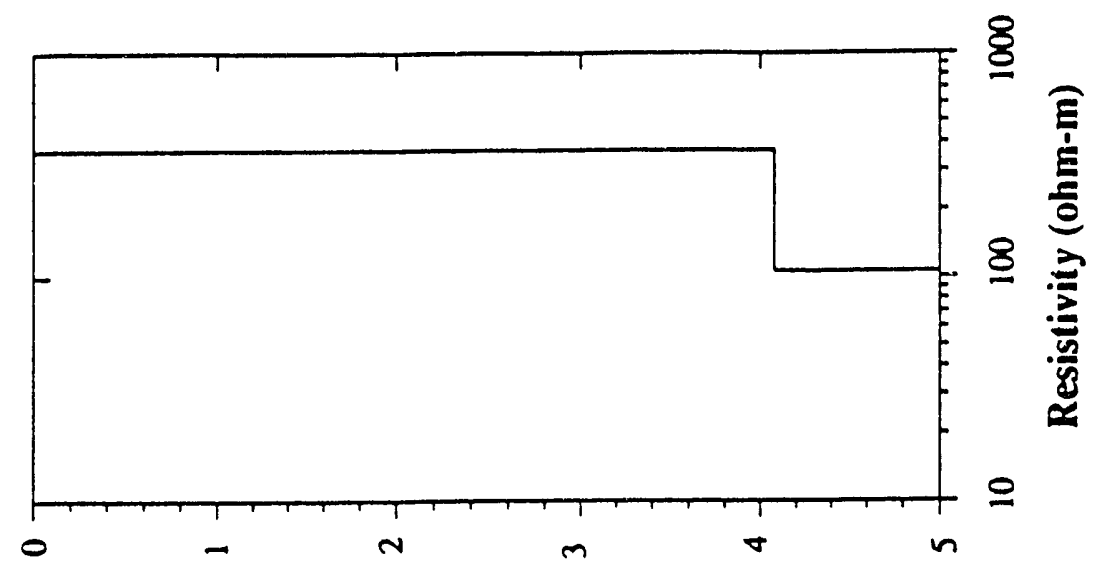

(I $\times$ ul) ч)da्a

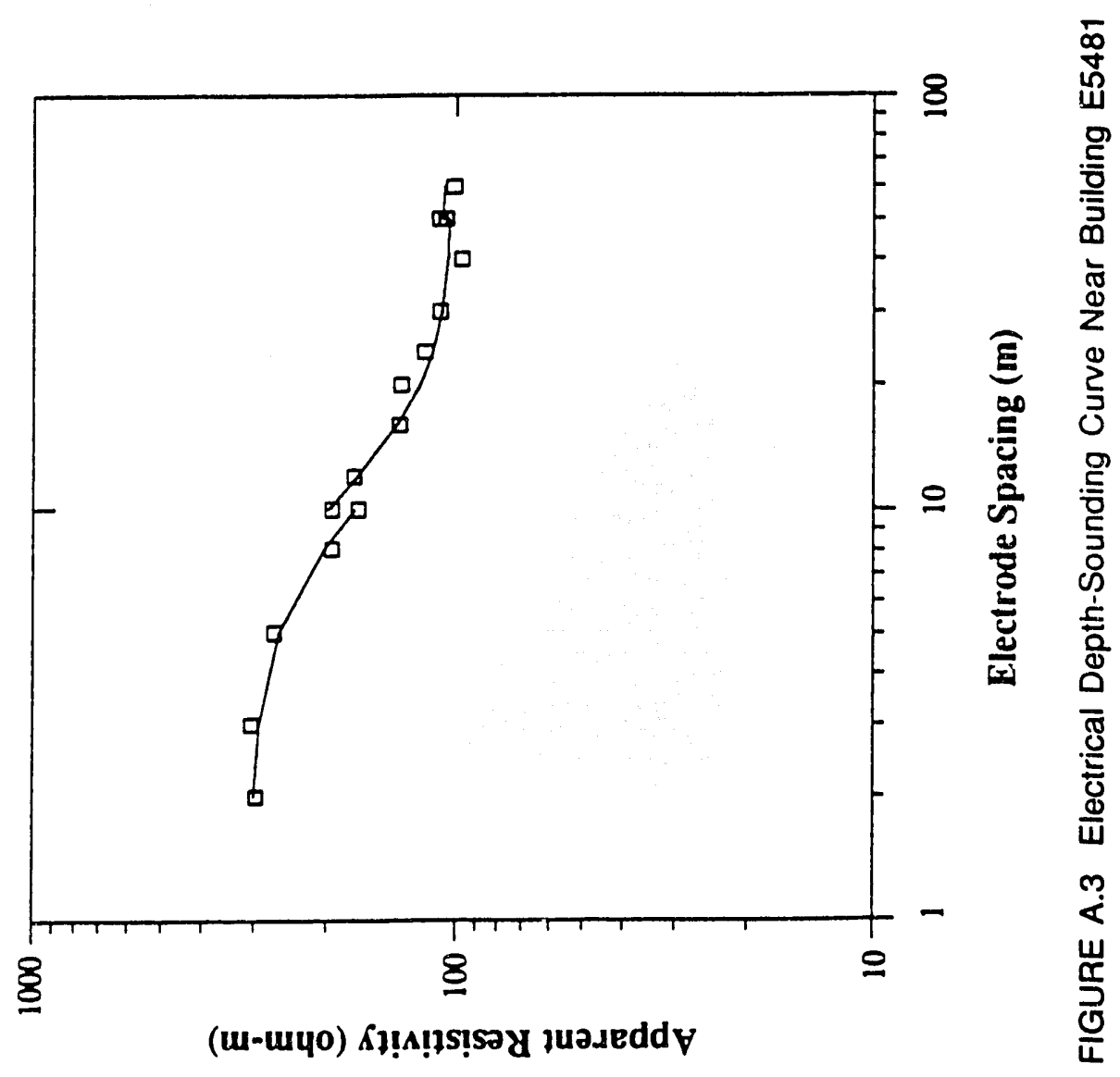



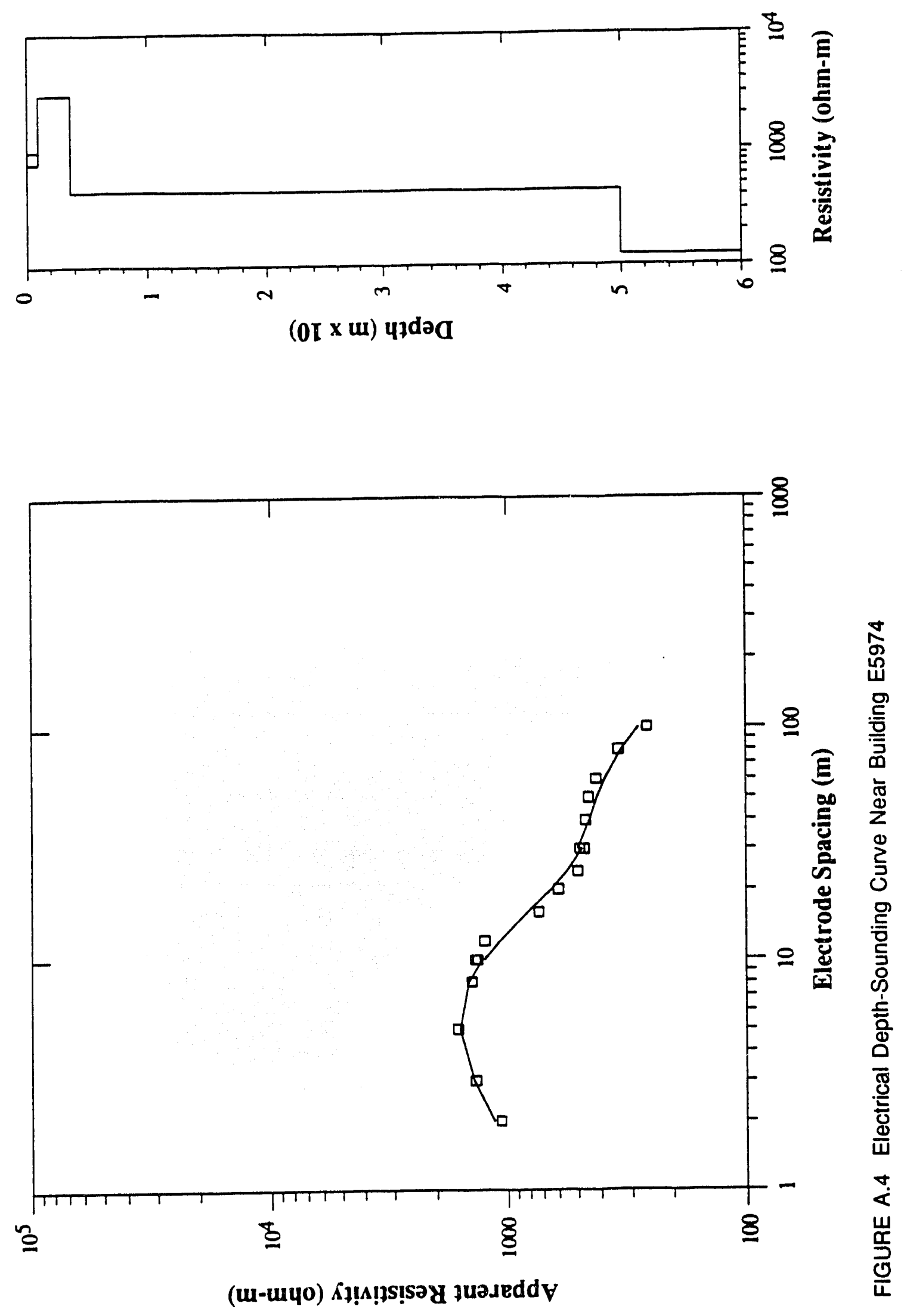


\section{Appendix B:}

Ground-Penetrating Radar Line Coordinates 


\section{Appendix B:}

Ground-Penetrating Radar Line Coordinates

\begin{tabular}{|c|c|c|c|c|}
\hline \multirow{2}{*}{$\begin{array}{l}\text { Line } \\
\text { No. }\end{array}$} & \multicolumn{2}{|c|}{$\begin{array}{c}\text { Start } \\
\text { Coordinates } \\
\end{array}$} & \multicolumn{2}{|c|}{$\begin{array}{c}\text { End } \\
\text { Coordinates }\end{array}$} \\
\hline & North & East & North & East \\
\hline 1 & 125 & 00 & 125 & 185 \\
\hline 2 & 125 & 05 & 05 & 05 \\
\hline 3 & 130 & 10 & 05 & 10 \\
\hline 4 & 130 & 15 & 05 & 15 \\
\hline 5 & 130 & 20 & 05 & 20 \\
\hline 6 & 130 & 25 & 05 & 25 \\
\hline 7 & 130 & 30 & 05 & 30 \\
\hline 8 & 130 & 35 & 05 & 35 \\
\hline 9 & 130 & 40 & 05 & 40 \\
\hline 10 & $13 c$ & 45 & 05 & 45 \\
\hline 11 & 130 & 50 & 45 & 50 \\
\hline 12 & 130 & 55 & 50 & 55 \\
\hline 13 & 130 & 60 & 50 & 60 \\
\hline 14 & 130 & 65 & 75 & 65 \\
\hline 15 & 130 & 70 & 75 & 70 \\
\hline 16 & 130 & 75 & 81 & 75 \\
\hline 17 & 130 & 105 & 81 & 105 \\
\hline 18 & 130 & 110 & 1 & 110 \\
\hline 19 & 130 & 115 & 81 & 115 \\
\hline 20 & 130 & 120 & 81 & 120 \\
\hline 21 & 130 & 125 & 81 & 125 \\
\hline 22 & 130 & $13 C$ & 81 & 130 \\
\hline 23 & 130 & 135 & 81 & 135 \\
\hline 24 & 130 & 140 & 70 & 140 \\
\hline
\end{tabular}

\begin{tabular}{|c|c|c|c|c|}
\hline \multirow{2}{*}{$\begin{array}{l}\text { Line } \\
\text { No. }^{a}\end{array}$} & \multicolumn{2}{|c|}{$\begin{array}{c}\text { Start } \\
\text { Coordinates } \\
\end{array}$} & \multicolumn{2}{|c|}{$\begin{array}{c}\text { End } \\
\text { Coordinates } \\
\end{array}$} \\
\hline & North & East & North & East \\
\hline 25 & 130 & 145 & 70 & 145 \\
\hline 26 & 130 & 150 & 80 & 150 \\
\hline 27 & 70 & 150 & 05 & 150 \\
\hline 28 & 50 & 145 & 05 & 145 \\
\hline 29 & 130 & 155 & 05 & 155 \\
\hline 30 & 130 & 160 & 85 & 160 \\
\hline 31 & 80 & 160 & 05 & 160 \\
\hline 32 & 130 & 165 & 05 & 165 \\
\hline 33 & 130 & 170 & 85 & 170 \\
\hline 34 & 75 & 170 & 05 & 170 \\
\hline 35 & 130 & 175 & 80 & 175 \\
\hline 36 & 80 & 175 & 05 & 175 \\
\hline 37 & 130 & 180 & 83 & 180 \\
\hline 38 & 80 & 180 & 05 & 180 \\
\hline 39 & 130 & 185 & 82 & 185 \\
\hline 40 & 80 & 185 & 05 & 185 \\
\hline 41 & 115 & 00 & 115 & 185 \\
\hline 42 & 100 & 00 & 100 & 70 \\
\hline 43 & i 5 & 00 & 85 & 190 \\
\hline 44 & 80 & 00 & 80 & 70 \\
\hline 45 & 75 & 00 & 75 & 70 \\
\hline 46 & 70 & 00 & 70 & 65 \\
\hline 47 & 65 & 00 & 65 & 64 \\
\hline 48 & 60 & 00 & 60 & 64 \\
\hline
\end{tabular}




\begin{tabular}{|c|c|c|c|c|}
\hline \multirow{2}{*}{$\begin{array}{l}\text { Line } \\
\text { No. }\end{array}$} & \multicolumn{2}{|c|}{$\begin{array}{c}\text { Start } \\
\text { Coordinates } \\
\end{array}$} & \multicolumn{2}{|c|}{$\begin{array}{c}\text { End } \\
\text { Coordinates } \\
\end{array}$} \\
\hline & North & East & North & East \\
\hline 49 & 55 & 00 & 55 & 64 \\
\hline 50 & 50 & 00 & 50 & 64 \\
\hline 51 & 45 & 00 & 45 & 50 \\
\hline 52 & 40 & 00 & 40 & 50 \\
\hline 53 & 35 & 00 & 35 & 50 \\
\hline 54 & 30 & 00 & 30 & 50 \\
\hline 55 & 25 & 00 & 25 & 50 \\
\hline 56 & 20 & 00 & 20 & 76 \\
\hline 57 & 15 & 15 & 15 & 50 \\
\hline 58 & 05 & 05 & 05 & 50 \\
\hline 59 & 70 & 137 & 70 & 185 \\
\hline 60 & 65 & 149 & 65 & 185 \\
\hline 61 & 60 & 149 & 60 & 185 \\
\hline 62 & 55 & 141 & 55 & 185 \\
\hline 63 & 50 & 137 & 50 & 185 \\
\hline 64 & 45 & 137 & 45 & 185 \\
\hline 65 & 40 & 137 & 40 & 185 \\
\hline 66 & 35 & 137 & 35 & 185 \\
\hline 67 & 30 & 145 & 30 & 185 \\
\hline 68 & 25 & 145 & 25 & 185 \\
\hline 69 & 20 & 145 & 20 & 185 \\
\hline 70 & 15 & 105 & 15 & 185 \\
\hline 71 & 10 & 66 & 10 & 185 \\
\hline
\end{tabular}

\begin{tabular}{|c|c|c|c|c|}
\hline \multirow{2}{*}{$\begin{array}{l}\text { Line } \\
\text { No. }\end{array}$} & \multicolumn{2}{|c|}{$\begin{array}{c}\text { Start } \\
\text { Coordinates }\end{array}$} & \multicolumn{2}{|c|}{$\begin{array}{c}\text { End } \\
\text { Coordinates }\end{array}$} \\
\hline & North & East & North & East \\
\hline 72 & 05 & 66 & 05 & 185 \\
\hline 73 & 00 & 170 & 20 & 170 \\
\hline 74 & 00 & 165 & 20 & 165 \\
\hline 75 & 00 & 160 & 20 & 160 \\
\hline 76 & 00 & 155 & 20 & 155 \\
\hline 77 & 00 & 150 & 20 & 150 \\
\hline 78 & 00 & 145 & 20 & 145 \\
\hline 79 & 130 & 155 & 90 & 155 \\
\hline 80 & 130 & 150 & 90 & 150 \\
\hline 81 & 130 & 145 & 90 & 145 \\
\hline 82 & 130 & 140 & 90 & 140 \\
\hline 83 & 130 & 140 & 90 & 140 \\
\hline 84 & 130 & 135 & 90 & 135 \\
\hline
\end{tabular}

a GPR lines 1-40 were collected at a range setting of $90 \mathrm{~ns}$ at $32 \mathrm{scans} / \mathrm{s}$, lines 41.72 were collected at a range setting of $90 \mathrm{~ns}$ at 16 scans/s, and lines 73-84 were collected at a range setting of $70 \mathrm{~ns}$ at $16 \mathrm{scans} / \mathrm{s}$. 

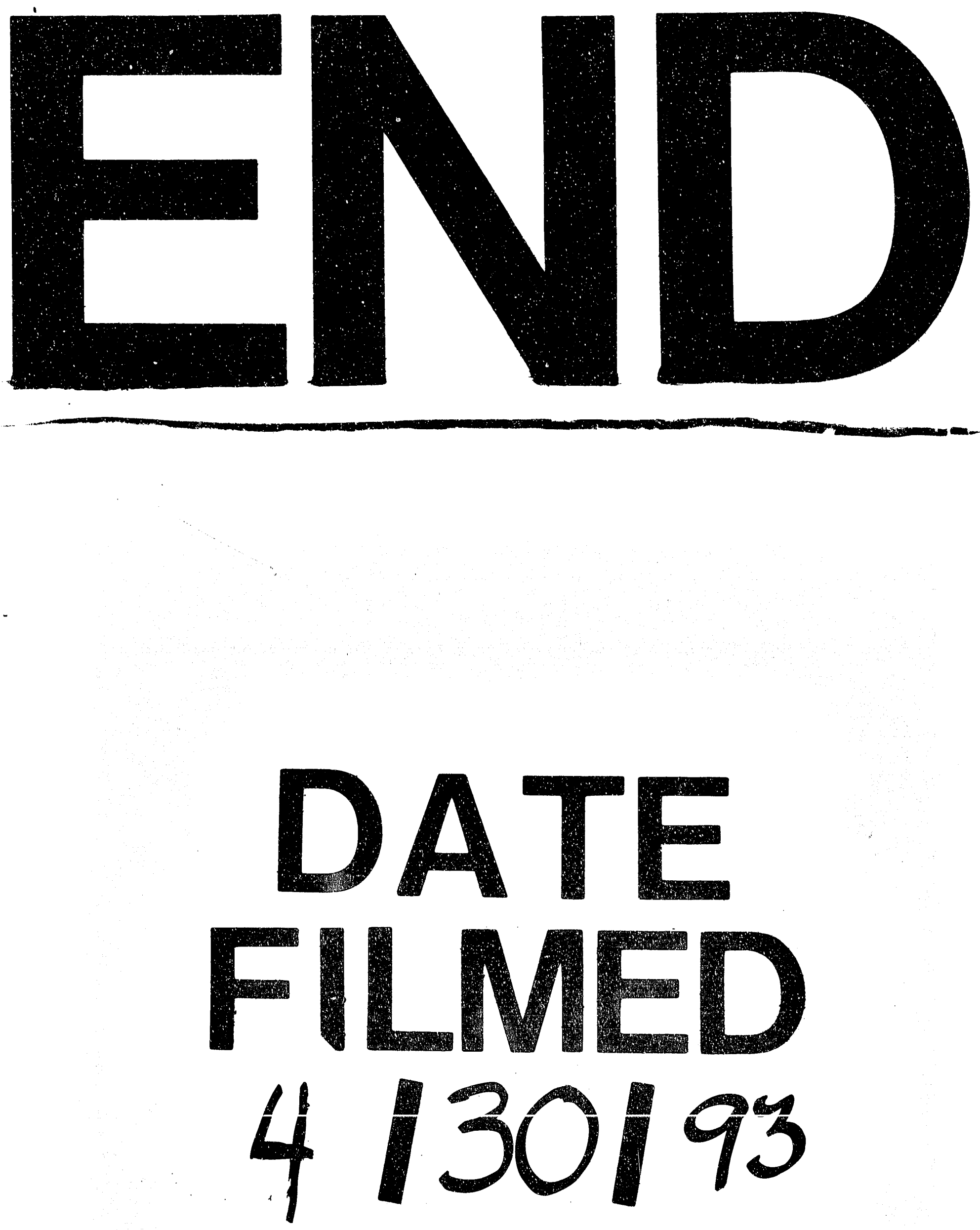
